\title{
Positioning Ethos in/for the Twenty-First Century: An Introduction to Histories of Ethos
}

\author{
James S. Baumlin ${ }^{1}$ and Craig A. Meyer ${ }^{2, *}$ \\ 1 Department of English, Missouri State University, Springfield, MO 65897, USA; JBaumlin@missouristate.edu \\ 2 Department of Language and Literature, Texas A\&M University-Kingsville, Kingsville, TX 78363, USA \\ * Correspondence: craig.meyer@tamuk.edu
}

Received: 3 July 2018; Accepted: 31 July 2018; Published: 9 August 2018

\begin{abstract}
The aim of this essay is to introduce, contextualize, and provide rationale for texts published in the Humanities special issue, Histories of Ethos: World Perspectives on Rhetoric. It surveys theories of ethos and selfhood that have evolved since the mid-twentieth century, in order to identify trends in discourse of the new millennium. It outlines the dominant theories-existentialist, neo-Aristotelian, social-constructionist, and poststructuralist-while summarizing major theorists of language and culture (Archer, Bourdieu, Foucault, Geertz, Giddens, Gusdorf, Heidegger). It argues for a perspectivist/dialectical approach, given that no one theory comprehends the rich diversity of living discourse. While outlining the "current state of theory," this essay also seeks to predict, and promote, discursive practices that will carry ethos into a hopeful future. (We seek, not simply to study ethos, but to do ethos.) With respect to twenty-first century praxis, this introduction aims at the following: to acknowledge the expressive core of discourse spoken or written, in ways that reaffirm and restore an epideictic function to ethos/rhetoric; to demonstrate the positionality of discourse, whereby speakers and writers "out themselves" ethotically (that is, responsively and responsibly); to explore ethos as a mode of cultural and embodied personal narrative; to encourage an ethotic "scholarship of the personal," expressive of one's identification/participation with/in the subject of research; to argue on behalf of an iatrological ethos/rhetoric based in empathy, care, healing (of the past) and liberation/empowerment (toward the future); to foster interdisciplinarity in the study/exploration/performance of ethos, establishing a conversation among scholars across the humanities; and to promote new versions and hybridizations of ethos/rhetoric. Each of the essays gathered in the abovementioned special issue achieves one or more of these aims. Most are "cultural histories" told within the culture being surveyed: while they invite criticism as scholarship, they ask readers to serve as witnesses to their stories. Most of the authors are themselves "positioned" in ways that turn their texts into "outings" or performances of gender, ethnicity, "race," or ability. And most affirm the expressive, epideictic function of ethos/rhetoric: that is, they aim to display, affirm, and celebrate those "markers of identity/difference" that distinguish, even as they humanize, each individual and cultural storytelling. These assertions and assumptions lead us to declare that Histories of Ethos, as a collection, presents a whole greater than its essay-parts. We conceive it, finally, as a conversation among theories, histories, analyses, praxes, and performances. Some of this, we know, goes against the grain of modern (Western) scholarship, which privileges analysis over narrative and judges texts against its own logocentric commitments. By means of this introduction and collection, we invite our colleagues in, across, and beyond the academy "to see differently." Should we fall short, we will at least have affirmed that some of us "see the world and self" —and talk about the world and self- - through different lenses and within different cultural vocabularies and positions.
\end{abstract}

Keywords: ethos; selfhood; identity; authenticity; authority; persona; positionality; postmodernism; haunt; iatrology; trust; storytelling; Archer; Aristotle; Bourdieu; Corder; Foucault; Geertz; Giddens; Gusdorf; Heidegger 


\section{Introduction}

A person's identity is not to be found in behaviour, nor-important though this is-in the reactions of others, but in the capacity to keep a particular narrative going. The individual's biography, if she is to maintain regular interaction with others in the day-to-day world, ... must continually integrate events which occur in the external world, and sort them into the ongoing "story" about the self.

—Anthony Giddens, Modernity and Self-Identity (Giddens 1991, p. 54)

Ethos is created when writers locate themselves.

—Nedra Reynolds, “Ethos as Location” (Reynolds 1993, p. 336)

"We seem able to approach ethos only within a set of paradoxes and ... contradictions" (Baumlin 1994, "Introduction", p. xxvi), writes James S. Baumlin:

We begin by outlining a fundamental opposition between Platonic and Aristotelian models of ethos-that is, between a theological or metaphysical truth and a verbally constructed appearance. We then chart the historical growth of consciousness and personhood, observing the relatively recent birth of self-consciousness, but we are immediately compelled, following Marxist and poststructuralist theories, to deny the singularity and stability of consciousness, authorship, voice, text, self. The nature of the self and its representations in language have fallen in doubt, not simply decentered or destabilized but radically questioned, questioned even as valid categories of being. Thrown into a crisis of interpretation, we confront a range of theories that would shatter the author's hypostatized voice into a set of textual functions, that would deny the speaker's conscious control over his or her now stratified, "heteroglot" language, that would refuse to locate the speaker or writer "inside" or "outside" (or anywhere), that would render self-presence and self-possession a bourgeois fiction, that would find authors like Derrida and Foucault and Barthes writing about the "death" of the author (a curious paradox, this). Where are we left? Does ethos remain ... a definable (or defensible) rhetorical concept? Is it at all useful? (Baumlin 1994, "Introduction", pp. xxvi-xxvii)

The questions above remain relevant and answerable, though our ways of answering must suit the needs of the twenty-first century. In effect, this present essay picks up where that previous survey-published more than a quarter-century ago-leaves off. Here, we focus on mid- to late-twentieth century discussions of ethos and remain on the lookout for traditions, trends, and ideas capable of carrying us into the new millennium. ${ }^{1}$ Excepting those places where Aristotelian theory has been reinterpreted, we find little need to repeat the 2500-year history of Western ethos. ${ }^{2}$ We seek, rather, to outline the current scholarly conversation, particularly in those places where ethos is being redefined, hybridized, and innovatively applied-or where it should be.

We write by way of introduction to the essay collection, Histories of Ethos: World Perspectives on Rhetoric. Here, the "histories" being told are, in large part, "other" than those subsumed within Western theory, and we intend this collection to be forward-looking, articulating possible futures for ethos and ethotic discourse. ${ }^{3}$ We proceed in Foucauldian manner, seeking not the "essential nature" of ethos but rather its engagements in intellectual discussion. In this regard, Nick Mansfield shows us

Seeing that ethos, pathos, and logos have entered common English vocabulary, we print them in roman.

Aristotle remains the singular exception: we cannot ignore the Aristotelian legacy (particularly in its vocabulary), since his Rhetoric continues to inform discussions of ethos today. For useful surveys of ethos in Western historical rhetoric, see Wisse (1989); Smith (2004); May (1988); Kennedy (1963, Art); Baumlin (2001, "Ethos"; 1994, "Introduction"). Discussions of individual theorists are recorded in notes following.

3 We take "discourse" expansively, as comprehending the realm of praxis in communication; we take "rhetoric" more restrictively, as representing the theories that categorize, explain/critique, and predict living discursive praxis. 
the way: "The question to be answered is not 'how do we get beyond these theories to the truth they aspire to ... ?' but 'what do the debates and theories themselves tell us about where we are placed in the history of culture and meaning-making?" (Mansfield 2000, Subjectivity, Kindle ed., pp. 174-78). He continues:

The insight that the genealogist seeks is not the truth that will finally make further discussion redundant, but how the discussion itself-with its wild inconsistencies and its bitter antagonisms, in which the rivals, like enemy armies in some famous battles, never quite seem to catch sight of each other-defines the way we live and represent ourselves. (Mansfield 2000, Kindle ed., pp. 178-80)

To paraphrase Mansfield, our task is not so much "to explain" ethos as "to reach a better understanding of how the issue" of ethos "has become so important to us" (Mansfield 2000, Kindle ed., p. 180). And its importance is hard to overstate, given that we live in an age of ethos: issues of "trust," expertise, and "charismatic authority" have largely supplanted Enlightenment logos or "good reasons" as the ground of popular discourse.

As Nedra Reynolds notes, "ethos ... shifts and changes over time, across texts, and around competing spaces" (Reynolds 1993, "Ethos as Location", p. 336). Tensions remain in most aspects of the current conversation, from etymology to application, and virtually every formulation of ethos finds itself situated within a binary opposition-a dialogue or dialectic of some sort. Our approach, thus, is genealogical: tracing terms back to their origins, we give each side a fair hearing, leaving readers to choose which version/s of ethos serve in which times and places within which specific exigencies before which specific audiences. ${ }^{4}$ The essays gathered in Histories of Ethos do tend to take sides; our task, here, is to outline the parameters of theory within each major debate. In effect, this present essay is a study of the contemporary "discourse of ethos-discourse," as reflected in our edited collection. ${ }^{5}$

As a term of rhetoric, ethos derives from Aristotle, who was first to theorize its praxis. His major discussion—from the Rhetoric 1.2.2-follows (Aristotle 1991):

[There is persuasion] through character whenever the speech is spoken in such a way as to make the speaker worthy of credence; for we believe fair-minded people to a greater extent and more quickly [than we do others] on all subjects in general and completely so in cases where there is not exact knowledge but room for doubt. And this should result from the speech, not from a previous opinion that the speaker is a certain kind of person; for it is not the case, as some of the technical writers propose in their treatment of the art,

4 In glancing Janus-like across histories and futures of ethos, we are indebted to Friedrich Nietzsche (1844-1900) (Nietzsche [1887] 1969) as well as to Foucault. Citing Bové's (1985) essay, "Mendacious Innocents" (pp. 367-69), Douglas Thomas writes,

Two of the key elements of Nietzsche's method of genealogical research are pointed out by Paul Bové: uncovering what is present ... and focusing on the future through a better understanding of the past .... Genealogical readings call for discoveries of an ever-present past, previously veiled or disguised, through the analysis of displacements, errors and chance in history, and provide new insight into the present. More important, genealogy gives new interpretations to the future. (D. Thomas 1993, “Utilising”, p. 104; emphasis added)

5 We take "contemporary" theory broadly, as falling within the epoch of postmodernism: as such, it reflects the state of intellectual culture after World War II, the Holocaust, and Hiroshima. Twenty-first century discussions of ethos remain in dialogue with mid- to late-twentieth century thought: with Kenneth Burke and Chaïm Perelman; with the later Heidegger; with the postwar existentialism of Georges Gusdorf and Maurice Merleau-Ponty; with Derridean deconstruction; with the social theories of Michel Foucault and Pierre Bourdieu; with postcolonialism and feminism; with the varieties of post-Freudian psychology (including behaviorism); with post-industrial capitalism and the rise of corporatism; with the posthuman interfaces of artificial intelligence. The post- in postmodernism declares much of what concerns us (and inspires us) in this essay collection. 
that fair-mindedness on the part of the speaker makes no contribution to persuasiveness; rather, character [ethos] is almost, so to speak, the controlling factor in persuading. (1356a) ${ }^{6}$

Yet Aristotle himself appropriated the term from Homeric poetry and pre-Socratic philosophy, where it inhabited different discursive spaces with different nuances of meaning. Even in its earliest appearances, ethos pulled in different directions, particularly as these are "contained within" variants of Greek etymology and usage. ${ }^{7}$ And contemporary theory—as reflected in textual criticism, media and communication studies, gender studies, law, theology, anthropology, sociology, psychology, ethics, politics, economics, even ecology - continues the fight over meanings and applications. Is ethos a verbal behavior or the "dwelling place" that contains such behavior? Does it belong to the speaker or to the audience (or to both, or to neither)? Does it dwell in the space "between" rhetor and audience? Is it a directed, symbolic action or a dialogic transaction? Is it revealed or constructed by means of speech? (Does it pre-exist speech? Does it "exist" at all?)

Like many terms from Greek philosophy (logos, pistis, kairos, to give a few) ethos remains untranslatable in any word-for-word correspondence. Numerous terms gesture in its direction, though no one word or phrase captures its nuances in English. Character, authority, charisma, credence, credibility, trust, trustworthiness, sincerity, "good sense," goodwill, expertise, reliability, authenticity, subjectivity, "the subject," self, selfhood, self-identity, image, reputation, cultural identity, habit, habitus, habituation, person, persona, impersonation, performance, self-fashioning, voice, personal style: these make for a sampling of stand-in terms. Theorists have played variations on the Aristotelian vocabulary: there's Jakob Wisse's (1989) "rational ethos" and "ethos of sympathy," Jim W. Corder's (1978) "generative ethos," Stephen K. White's (2009) "ethos of citizenship," Robert K. Merton's (1973) "scientific ethos," Michael W. DeLashmutt's (2011) "cyborg ethos," Liesbeth Kothals Altes' (2014) "narrative ethos," John Oddo's (2014) "intertextual ethos," Kristie S. Fleckenstein's (2016) "photographic ethos," Valerie Palmer-Mehta's (2016) "feminist ethos," Stacey Waite's (2016) "queer ethos," Gayatri Chakravorty Spivak's (1988) "ethos of the subaltern," and so on. Theorists have coined their own terms suggestive of ethos: there's the Freudian ich or ego-consciousness (heir to the Cartesian cogito), the Jungian "Self," the Heideggerian Dasein, the Burkean "agent," the Sartrean pur soi ${ }^{8}$, the Lacanian sujet divisé $e^{-}$, the Gusdorfian parleur, the Barthesian auteur, etc.

There are patterns in these lists. Some terms point to the existential components of ethos; some to its sociological/cultural expressions; some to its linguistic/discursive praxis. Indeed, the terms above serve as our hunting ground. For it seems that any adequate "map" or model of ethos will include $a$ version of self and of its relation to culture and language. Equally important is the insight that each theory orients itself from (and, in so doing, privileges) one of three perspectives: that of self, or of culture, or of language.

We begin with an existentialist presumption of an ontology of self, which "expresses" or reveals itself by language. ${ }^{10}$ Within this model, the self is real-a being-in-the-world. It may need language

6 Here and elsewhere, we follow George A. Kennedy's translation (Aristotle on Rhetoric). W. Rhys Robert's translation of this last phrase, however, is rather more emphatic: "On the contrary, his character may almost be called the most effective means of persuasion he possesses" (Aristotle 1941, Basic Works, p. 1329).

7 Our task might have simplified had Aristotle restricted the term to his triad of pisteis_ethos, logos, and pathos-as outlined in Book I of the Rhetoric. Yet the varieties of '"character' - not just of the speaker, but of the 'judge' in law courts and assemblies, of various audiences, of different communities, and as depicted in narrative-function in different ways in discourse" (Baumlin 2001, "Ethos", p. 267); emphasis added). Within these varied functions, Aristotle "establish[es] their etymological 'family resemblances' as $\tilde{\eta} \theta 0 \varsigma$ (that is, 'rational ethos' or a speaker's rhetorically-constructed character), है $\theta \circ \varsigma$ (that is, moral character as reflected in "custom" or "habit"), $\eta \theta \eta$ (that is, the various character types identifiable with each

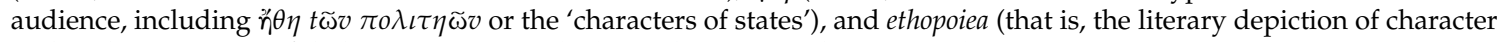
within the structures of dialogue or narrative)" (Baumlin 2001, "Ethos", p. 267).

8 See (Sartre [1943] 1993, Being and Nothingness, Hazel E. Barnes, trans.).

9 See (Lacan 2004, Ecrits: A Selection, Bruce Fink, trans.).

10 We cite Georges Gusdorf (1912-2000) in this regard, who declares expression a necessary "coefficient of speech" (Gusdorf 1965, Speaking, p. 70), such that "the whole of human experience in its militant sense may be understood as 
to reveal itself (Heidegger), but its existence precedes discourse. ${ }^{11}$ Giving the "essential nature" of the self, an existentialist model seeks an ethos of "authenticity." In contrast, a social-constructionist model privileges culture over self, often reducing the self to a repertoire of behaviors-of cultural "rules" and "recipes." Within such a model, the self is constructed by language and other modes of cultural-symbolic communication/participation. Here the self has no meaning—no "being"—outside of its cultural container; and, since the self "enacts itself" within specific roles and behaviors, its "nature" (if such a term applies here) arises in performance. ${ }^{12}$ The self, in this sense, is a mode of personation-a mask. ${ }^{13}$ Within such a model, ethos gives the "roles" (Goffman) and "rules" (Geertz) of the socially-constructed self.

In even greater contrast, poststructuralist models privilege language over self and culture alike. Within such a model, the self-expressive self "dissolves" within the interstices of texts. Following Jacques Derrida (1930-2004), deconstructionists declare writing's primacy over speech: "orphaned" from the living, embodied voice of the speaker, the written text confesses its loss of authorial presence (Derrida 1981, Dissemination, p. 148). Indeed, the author's "death" is proclaimed-though with little mourning. ${ }^{14}$ Within such a model, one cannot say that the self "textualizes" itself: that, after all, would posit the speaking/writing subject as a point of origin whose existence precedes language. Rather, the self reduces to a grammatical function, a mere pronoun: "I." Stuart Hall states this position in its extreme: "Identities," he writes, "are points of temporary attachment to the subject positions which discursive practices construct for us. They are the result of a successful articulation or 'chaining' of the subject into the flow of discourse" (Hall and Gay 1996, "Who Needs", p. 6). Within this model, notions of selfhood—whether existential or cultural in origin—remain mere fictions, textually inscribed. ${ }^{15}$

These versions of selfhood provide rhetoric with its enabling premises, upon which it has built its contemporary versions of ethos. We should note, however, that such premises cannot be proved from within the discourses that they generate. ${ }^{16}$ Competing versions, thus, are the starting points of

a striving for expression" (p. 73). Within an interpersonal self/other dialectic, one's "relation to others," notes Gusdorf, "is only meaningful insofar as it reveals that personal reality within the person who is himself speaking. To communicate, man expresses himself" (p. 69; emphasis added). Here and elsewhere, we regret the masculinist vocabulary embedded in such texts.

11 Theologian Roger Trigg articulates this position: "So far from the differentiation between subject and object being the consequence of a concentration on language, language itself depends on it. The self cannot be constituted by language. It is presupposed by it" (Trigg 1998, Rationality, p. 159).

12 "Whatever else the self is," writes James T. Tedeschi, "it is developed in the context of relationships with others during which self-presentational behavior is performed" (Tedeschi 1986, "Private and Public", p. 5). Tedeschi presents an extreme version of the social-performative model:

Indeed, if one removed the identities of the individual as a parent, sibling, offspring, productive worker, and so on, it is doubtful there would be anything left to refer to as the self. Other aspects of the self, such as competence, moral qualities, and character traits, also have meaning only in the context of social interactions. (Tedeschi 1986, "Private and Public", p. 5)

13 Indeed, the Latin persona translates literally as "mask" (Baumlin 1994, "Introduction", p. xii), the sort worn by actors on public stage (hence the dramatis personae or "cast of characters" in drama). Erving Goffman (1922-1982) elaborates on the social "mask": it is "a recognition of the fact that everyone is always and everywhere, more or less consciously, playing a role .... It is in these roles that we know each other; it is in these roles that we know ourselves" (Goffman 1959, Presentation, p. 19).

14 Roland Barthes (1915-1980) argues similarly: “Writing is the destruction of every voice, every origin. Writing is that ... obliquity into which our subject flees, the black-and-white where all identity is lost, beginning with the very identity of the body that writes" (Barthes 1986, “Death", p. 49). In writing, thus, "the author enters into his own death" (Barthes 1986, “Death”, p. 49).

15 Pertaining to personal and cultural narratives alike, identities arising from a "narratization of the self" are, Hall declares, "necessarily fictional" in nature (Hall and Gay 1996, "Who Needs", p. 4). Such claims return us to the question of ontology. "This view," writes Margaret S. Archer, "elides the concept of the self with the self of self: we are nothing but what society makes us, and it makes us what we are through our joining society's conversation. However, to see us as purely cultural artifacts is to neglect the vital significance of our embodied practice in the world" (Archer 2001, Being Human, p. 4).

16 Put baldly, discourse cannot prove what it must "take for granted." In summarizing Judith Butler's critique of natural or real vs. "fantasized" bodies, Nick Mansfield elaborates on this point: "the very identification of a nature and a reality that pre-exist culture is itself a model produced within culture, another 'culturally instituted fantasy'" (Mansfield 2000, Subjectivity, Kindle ed., pp. 1334-36). He continues: 
discussion, by means of which we can organize our explorations of the varieties of ethos and ethotic discourse. Through the following paragraphs, we elaborate on several versions of self and the theories they enable.

We begin with a working definition provided by Jim W. Corder (1929-1998). Ethos, Corder writes, is "character as it emerges in language" (Corder 1978, "Varieties", p. 2). ${ }^{17}$ By "character," we assume both personhood and persona-that is, the self's expressive self-identity as well as its social presentation or mask. There is a double movement, both inward and outward, in this term, which introjects how one "sees" oneself, as well as projects how one "is seen" by others. One hopes for sincerity, authenticity, and self-consistency in this doubled, inside/outside "showing-forth" of character. When inside and outside match, one can speak of ethos as self-revelation: "what you see is what you get." But there can be a slippage or disjunction between the person and persona-again, between the inner and the outer versions of self. In that case, one can speak of ethos as performance. ${ }^{18}$

To this inside/outside dialectic, let us add considerations of culture. Character "emerges," but does so within a distinctive "cultural dress," one that presents itself-in effect, "clothes itself" - within markers of identity/difference (ethnicity, gender, social status, regional accent, etc.). Michel Foucault (1926-1984) gives the Athenian ethos as illustration: "Ethos was the deportment and the way to behave. It was the subject's mode of being and a certain manner of acting visible to others. One's ethos was seen by his dress, by his bearing, by his gait, by the poise with which he reacts to events, etc." (Foucault 1987, "Ethic of Care", p. 6; emphasis added). Ethos, in this sense, displays cultural "markers,"19 such that the speaker's task is "to open a space" through language that allows the self to be heard and, saliently, to be seen. Adding the self/other binary to this model, we note that speakers position themselves against hegemonic counter-discourses that, historically, have served to efface or oppress cultural "difference."

The belief that there are categories that exist independent of and prior to the systems that theorise them is an act of faith, produced within a specific culture at a specific time in its history. The idea of a "real" biological body, which depends on culture's guess work about what exists outside of culture, must equally be seen as an object of belief, rather than an immutable fact. Gender, therefore, is neither a result of nature's own categories, nor an interpretation appended to them. Distinctions attributed to nature are only produced from within culture-in other words, within gender. (Mansfield 2000, Subjectivity, Kindle ed., pp. 1336-40)

The same qualifications hold for an ontology of the self, which we are content to take "as an object of belief, rather than an immutable fact." As such, we can theorize about the embodied self- that is, we can talk about it—without claiming to know more than we can "know" or prove.

17 As we've seen, Georges Gusdorf makes use of this same vocabulary: “To speak," writes Gusdorf, "is to wake up, to move toward the world and others. Speaking actualizes an emergence" (Gusdorf 1965, Speaking, pp. 93-94; emphasis added).

18 Goffman's influential Presentation of Self (1959) asserts the "moral character of projections" (p. 13): "Sociology is organized on the principle that any individual who possesses certain social characteristics has a moral right to expect that others will value and treat him in an appropriate way" (p. 13). He continues:

Connected with this principle is a second, namely that an individual who implicitly or explicitly signifies that he has certain social characteristics ought in fact to be what he claims he is. In consequence, when an individual projects a definition of a situation and thereby makes an implicit or explicit claim to be a person of a particular kind, he automatically exerts a moral demand upon the others, obliging them to value and treat him in the manner that persons of his kind have a right to expect. He also foregoes all claims to be things he does not appear to be .... The others find, then, that the individual has informed them as to what is and as to what they ought to see as the "is." (Goffman 1959, Presentation, p. 13)

19 For discussions/applications of genetic and cultural "markers of identity," see essays in the special issue of Racial and Ethnic Studies 26.2 (2016). We have broadened our use of "markers" to include all expressions (mental, physical, social, demographic) of difference - of the ways that self-identity, cultural identity, and linguistic identity function within a self/other binary. We accept, as a matter of course, the anthropological perspective and its relevance to ethos. "We are," writes Clifford Geertz (1926-2006), "incomplete or unfinished animals who complete or finish ourselves through culture-and not through culture in general but through highly particular forms of it: Dobuan and Javanese, Hopi and Italian, upper-class and lower-class, academic and commercial" (Geertz 1973, Interpretation, p. 113). As Geertz notes further, our "great capacity for learning ... has often been remarked," but even more crucial is our "extreme dependence upon a certain sort of learning: the attainment of concepts, the apprehension and application of specific systems of symbolic meaning" (p. 113). These "systems of symbolic meaning" constitute culture, which, in turn, conditions individual human experience, expression, and self-image. 
Though neoliberalism aspires to a universalized, rational model of "'human being'-a creature eventually, ultimately, to be seen without color" or other markers of identity (Sennett 1990, "Racial Identity", p. 192)—we follow Foucault in questioning whether "there can be a society without relations of power, if you understand them as means by which individuals try to conduct, to determine the behavior of others" (Foucault 1987, "Ethic of Care", p. 18). Foucault elaborates:

The problem is not of trying to dissolve them in the utopia of a perfectly transparent communication, but to give one's self the rules of law, the techniques of management, and also the ethics, the ethos, the practice of self, which would allow these games of power to be played with a minimum of domination. (Foucault 1987, "Ethic of Care", p. 18)

The "utopia" that Foucault derides remains a dream-motif of the Enlightenment, whose aspirations toward universalism - toward a genuinely race-, gender-, and color-blind discourse - continue to define the (post-)modern academy. ${ }^{20}$

Over against "the utopia of a perfect transparent communication," one confronts the "games of power" embedded in discourse. By these "games," Foucault addresses a specific function of ethos: along with a speaker's "cultural dress," ethos identifies the ritualized modes of address that confer authority upon those who would "speak on behalf" of some group-some institution, organization, party, or class interest. For "groups need representation," notes Karl Maton, "since they cannot speak as a group. They therefore invest their moral authority in ... individuals who, thus consecrated, are the voice 'of the people' - a claim to which they give tacit assent" (Maton 2014, "Habitus", p. 56); emphasis added). In the following, we switch theorists (and vocabularies) from Foucault to Pierre Bourdieu (1930-2002) though, again, we draw our example from antiquity.

In the warrior-council of Book I of the Iliad, Agamemnon demands the slave girl, Briseis, from Achilles. Insulted, the Achaean champion begins to draw his sword. But, visited by Athena (who tempers his wrath), Achilles returns it to its sheath. In its stead, Achilles wields a different instrument, the $\sigma \kappa \tilde{\eta} \pi \tau \rho o v$ - the skeptron or "scepter" (or, as A. T. Murray translates it below, "staff"), by which he speaks a dire, "mighty oath":

But the son of Peleus again addressed with violent words the son of Atreus ... . "Heavy with wine, with the face of a dog but the heart of a deer, never have you had courage to arm for battle along with your people ... else, son of Atreus, this would be your last piece of insolence. But I will speak out to you, and will swear thereto a mighty oath: by this staff $[\sigma \kappa \tilde{\eta} \pi \tau \rho o v]$ that shall never more put forth leaves or shoots since first it left its stump among the mountains, nor shall it again grow green, for ... the sons of the Achaeans carry it in their hands when they act as judges ... this shall be for you a mighty oath. Surely some day a longing for Achilles will come upon the sons of the Achaeans one and all, and on that day you will not be able to help them ... when many shall fall dying before man-slaying Hector. But you will gnaw the heart within you, in anger that you did no honour to the best of the Achaeans." (Iliad 1.222-44)

In Homer, the skeptron "is the attribute of the king, of heralds, messengers, judges, and all persons who, whether of their own nature or because of a particular occasion, are invested with

20 While we remain hopeful in the possibility of living harmoniously as "free, rational, and responsible being[s]" (White 2009, Ethos, pp. 26-27), we concur with Stephen K. White's post-Enlightenment critique of the "ideal of self":

[The Enlightenment ethos] does not incorporate all of what, over the last few decades, has been referred to with the phrases "identity politics" and "the politics of recognition." These phrases draw our attention beyond respect for the individual in the universalist sense, to the acknowledgment of people's diversity, their distinctiveness in language, religion, sexuality, nationality, and traditional practices. (White 2009, Ethos, pp. 26-27)

In sum, the Enlightenment model of self remains logocentric, not ethocentric. White adds, "this demand that one's identity be acknowledged in its distinctiveness, or difference, is one of the most controversial subjects in contemporary political theory" (White 2009, Ethos, pp. 26-27). Indeed: and it remains a focus of contemporary rhetorical theory. 
authority" (Bourdieu 1991, Language, p. 193). But, as Bourdieu states elsewhere, this "authority comes to language from outside, a fact concretely exemplified by the skeptron that, in Homer, is passed to the orator who is about to speak. Language at most represents this authority, manifests and symbolizes it" (Bourdieu 1991, Language, p. 109; emphasis added). ${ }^{21}$ A speaker's assumption of authority, thus, is not a consequence of ethos (as per Aristotle); rather, it is a precondition-a "given," and accessed by means of the skeptron.

Like other cultural practices, public discourse has its "plans, recipes, rules, instructions" (Geertz 1973, Interpretation, p. 51), which speakers are assumed to adopt or adapt in positioning themselves as having, not just the right to speak, but to be heard in speaking. Within specific institutions, organizations, and communities, there are authoritative/charismatic roles as well as rules: priest, novitiate, judge, tribal elder, teacher, apprentice, employee, manager, salesperson, politician, political commentator, soldier, athlete, scientist, rap artist ... each with its distinctive "speech genres" (Bakhtin 1986), social rituals, and stylistic/expressive strategies. ${ }^{22}$ The question that postmodern culture poses is one of competing voices unequally positioned with respect to power: Who speaks for whom, and by what instrument or means?

Continuing his analysis, Bourdieu finds material symbols of authority in contemporary media:

The abundance of microphones, cameras, journalists and photographers, is, like the Homeric skeptron ... the visible manifestation of the hearing granted to the orator, of his credit, of the social importance of his acts and his words. Photography-which, by recording, eternizes-has the effect ... of solemnizing the exemplary acts of the political ritual. (Bourdieu 1991, Language, p. 193; emphasis in original)

While the camera records a speaker's visual presence, it's the microphone that stands in for the skeptron today. As women and people of color have learned too well, the difficulty in achieving social justice-in being seen and heard, whether individually or as a group-lies not in refutation within public debate, but in practices of silencing: that is, of being denied the skeptron. ${ }^{23}$ Having placed rituals of authority "outside of language" and having acknowledged their cultural contexts, we're ready to turn to Aristotle.

\section{Aristotle: Ethos as "Character"}

Rhetorical theory of the mid-twentieth century wedded itself to Aristotle (384-322 BCE). His Rhetoric had already saturated nineteenth-century scholarship, displacing Ciceronianism from its two-thousand-year reign; still, it was in the mid-twentieth century that Aristotle became the dominant authority in "academic rhetoric" - particularly within composition programs as these were beginning

21 In fact, the conferring of authority belongs to "rituals of social magic" (Bourdieu 1991, Language, p. 111). The "magic" of such rituals, Bourdieu adds, "does not reside in the discourses and convictions which accompany them ... but in the system of social relations which constitute ritual itself, which make it possible and socially operative" (Bourdieu 1991, Language, p. 268 fn. 6; emphasis added).

22 Susan Miller notes the "various forms of instruction" in moral character that are "threaded through the identities of seer, prophet, poet, physician, philosopher, hero, and orator" (Miller 2007, Trust, p. 34):

In different ways that link these figures, each mediates between sacred truths that comfort us as assurance that more than we know might become known and the illusion that we know more already insofar as these figures make statements we trust but cannot verify. And paradoxically, what is said of those secrets is trusted in proportion to its ability to be unsettling". (Miller 2007, Trust, p. 34; emphasis added)

In other words, we rely on charismatic authority "to know" what we cannot know ourselves.

23 In this respect, political demonstrations are expressive in function: that is, they create the political identity of those who "enact themselves" as demonstrators within "the act" of demonstrating. So Bourdieu suggests: "by demonstrating the demonstrators and, above all, the leaders of the demonstration, the demonstration demonstrates the existence of the group capable of demonstrating its existence and of leaders who can demonstrate its existence-thereby justifying their existence" (Bourdieu 1991, Language, p. 193). But demonstrations "work" only if they are covered by mic and camera. (The collapse of the "Occupy Wall Street" movement came when local news stations, pressured by city governments and chambers of commerce, ceased regular coverage.) 
to evolve out of departments of English. The so-called "Chicago School" built its critical foundations upon the Aristotelian canon; supplanting the old, belletristic "current-traditional rhetoric," the "New Rhetoric" (as it came to be called) was, in large part, a revival of Aristotelianism strengthened by new translations, editions, and commentaries (Cooper 1932 ${ }^{24}$; Freese 1926 ${ }^{25}$; Grimaldi 1980, 1988; Aristotle 194126; Roberts 1941; Solmsen 194127; Wisse 1989; Kennedy 1963). Even where the "New Rhetoric" sought to expand its vocabularies and boundaries (Perelman and Olbrechts-Tyteca 1969; Burke 1969), it did so extensively in dialogue with Aristotelian classicism. ${ }^{28}$ Aristotle's dominance is readily explained: his systematic approach; his "demystifying" of persuasion (as opposed to the "irrationalism" of Gorgianic apate and the theology underlying Plato's psychagogia), ${ }^{29}$ and, above all, his commitment to "reason" (logos) reinforced the intellectual foundations of modernism. In sum, Aristotelian rhetoric served the Enlightenment discourses of science, technology, and neoliberal political philosophy. For, logocentric in its linguistic epistemology, the Rhetoric articulates a "rational ethos" (Wisse 1989, Ethos and Pathos, p. 33) that appealed to postwar Western intellectual culture.

There's an elegant symmetry in the Rhetoric, which outlines three pisteis or modes of "artistic proof" (1.2.2.), these being logos (an offering of "good reasons"), pathos (an appeal to an audience's emotions), and ethos (an appeal for an audience's trust). In another major passage (Rhetoric 2.5.7) Aristotle identifies the components of ethos specifically, "for there are three things we trust other than logical demonstrations" (Aristotle 1991):

These are practical wisdom [phronesis] and virtue [arete] and goodwill [eunoia]; for speakers make mistakes in what they say or advise through [failure to exhibit] either all or one of these.... Therefore, a person seeming to have all these qualities is necessarily persuasive to the hearers. (Rhetoric 1378a)

24 See (Aristotle 1932, The Rhetoric of Aristotle, Lane Cooper, trans.).

25 See (Aristotle 1926, Aristotle: The 'Art' of Rhetoric, John H. Freese, trans.)

26 See (Aristotle 1941, The Basic Works of Aristotle, Richard McKeon, ed., W. Rhys Roberts, trans).

27 See (Aristotle 1941, The Basic Works of Aristotle, Richard McKeon, ed., W. Rhys Roberts, trans).

28 In her introduction to the 2007 essay collection, What is the New Rhetoric? Susan E. Thomas acknowledges the classical legacy:

Since the 1960s, the definitions of "new rhetoric" have expanded to encompass a variety of theories and movements, raising the question of how rhetoric is understood and employed in the twenty-first century. When scholars and business leaders gathered at the University of Sydney on 3 September 2005 to discuss "What is the New Rhetoric?," three major themes emerged:

1. How the classical art of rhetoric is still relevant today;

2. How it is directly related to modern technologies and the new modes of communication they have spawned;

3. How rhetorical practice is informing research methodologies and teaching and learning practices in the contemporary academy. (S. E. Thomas 2007, p. 1)

29 Describing persuasion as an apate or "deliberate deception," the sophist Gorgias (c. 485-c. 380 BCE) claimed for rhetoric a power of witchcraft:

Speech is a powerful lord, which by means of the finest and most invisible body effects the divinest works: it can stop fear and banish grief and create joy and nurture pity .... Sacred incantations sung with words are bearers of pleasure and banishers of pain, for, merging with opinion in the soul, the power of the incantation is wont to beguile it and persuade it and alter it by witchcraft. (Gorgias 1990, “Encomium", p. 42)

Whereas Gorgias aims at deception, Plato's Socrates practices "a psychagogia or leading of the soul to truth" (Baumlin 2001, "Ethos", p. 264). As Socrates asks his young interlocutor, Phaedrus, "Is not rhetoric in its entire nature an art which leads the soul [ $\psi v \chi \alpha \gamma \omega \gamma$ i $\alpha$ ] by means of words ... ?" (Plato 1966, Phaedrus, 261a-b).Platonic ethos assumes the moral and, ultimately, theological inseparability of the speaker-agent from the speech-act. Indeed, "Plato is uncompromising in asserting this equation: truth must be incarnate within the individual, and a person's language must express (or, first, discover) this truth. Conversely, any attempt to separate a person's speech from his actual character serves to deny the incarnational aspect of truth and discourse alike. As Socrates says to Phaedrus, "If we are to address people scientifically, we shall show them precisely what is the real and true nature of that object on which our discourse is brought to bear. And that object, I take it, is the soul" (Plato 1966, Phaedrus, 270e; emphasis added). 
Commenting on this passage, James L. Kinneavy and Susan C. Warshauer note the "complex interrelation among speaker, hearer, and subject matter" in Aristotle's system, such that "arete refers to the speaker, eunoia to the audience, and phronesis to the subject matter" (Kinneavy and Warshauer 1994, "From Aristotle", p. 179). In fact, phronesis refers to the logos-aspect of ethos, eunoia to the pathos-aspect, and arete to ethos or "moral character" per se. We can add that logos-"rational appeal" or the use of "good reasons"- originates with/in the rhetor, though audiences are left to judge its claims and to respond accordingly. And whereas pathos-an appeal to the audience's pathe or emotions-is raised by means of a rhetor's appeals, it's with/in the audience that hope or fear or outrage or desire is raised. In this sense, the Aristotelian logos "belongs to" the rhetor and is judged by the audience, while pathos "belongs to" the audience and is elicited by the rhetor. In contrast, ethos "lies between" the speaker and audience: belonging to neither wholly, the rhetor's ethos is built out of a speaker-audience interaction.

Though Aristotelian ethos describes a responsive, transactional model, there is one passage in the Rhetoric that, taken at face value, radically textualizes the speaker's self-presentation. We've quoted it earlier: it's the declaration that persuasion "through character ... should result from the speech," and "not from a previous opinion that the speaker is a certain kind of person" (Rhetoric 1356a; emphasis added). If trust comes "from the speech" solely, then the speaker's ethos is fashioned from within discourse and becomes part of the discourse in its totality. Such a claim contradicts the teachings of Aristotle's older contemporary, Isocrates (436-338 BCE), for whom "the power to speak well is taken as the surest index of a sound understanding, and discourse which is true and lawful and just is the outward image of a good and faithful soul" (Isocrates 1990, "Antidosis," p. 327). Weighed against Athenian tradition, Aristotle's textually-constructed ethos is an anomaly, repeated nowhere else in theory or in praxis. ${ }^{30}$

In contemporary poststructuralist terms, the Aristotelian rhetor is reduced to an effect of language: exactly "who" the speaker "is" depends on how the audience "reads" him. If the audience "reads" him as being worthy of trust, then the Aristotelian rhetor's ethos-maneuvers will have succeeded. Whether the rhetor deserves that trust remains an ethical question lying outside the text. And, within this radically textualized model, the ethics of ethos must "lie outside," since Aristotle's Rhetoric undergirds an ethos of appearances.

Having established the importance of a speaker's apparent truthfulness, Aristotle turns to the audience and ways "to prepare" "the judge" for a favorable impression (Rhetoric 2.2-4):

But since rhetoric is concerned with making a judgment (people judge what is said in deliberation, and judicial proceedings are also a judgment), it is necessary not only to look to the argument, that it may be demonstrative and persuasive but also [for the speaker] to construct a view of himself as a certain kind of person and to prepare the judge; for it makes much difference in regard to persuasion ... that the speaker seem to be a certain kind of person and that his hearers suppose him to be a certain kind of person and that his hearers suppose him to be disposed in a certain way. (Rhetoric 1377b)

Words like "construct," "suppose," and "seem" point to the amorality of rhetoric generally while transforming Aristotelian ethos into an effect of speech, "separate from any consideration of the

30 We wonder if scholars have made too much of Rhetoric 1356a. As unpublished lecture notes, the Rhetoric contains numerous interpolations, repetitions, and contradictions; how much weight Aristotle himself would have given to this passage remains a point of speculation. But there is one point that we can make with certainty: it was the school of Isocrates, not of Aristotle, that trained Athenians in rhetorical paideia; and, for Isocrates, reputation necessarily precedes (and informs) one's speaking. Thus, "the man who wishes to persuade people will not be negligent as to the matter of character; no, on the contrary,"

He will apply himself above all to establish a most honorable name among his fellow-citizens; for who does not know that words carry greater conviction when spoken by men of good repute than when spoken by men who live under a cloud, and that the argument which is made by a man's life is of more weight than that which is furnished by words? (Isocrates 1990, "Antidosis", p. 339; emphasis added) 
speaker's prior reputation or 'true' moral character" (Baumlin 2001, "Ethos", p. 266). ${ }^{31}$ Within this constructionist model, the rhetorical situation renders the speaker an element of the discourse itself, "no longer simply its origin (and thus a consciousness standing outside of or prior to the text) but, rather, a signifier standing inside an expanded text. The rhetor's physical presence and appearance, gestures, inflections, and accents of style, all become invested in acts of signification," whose objective is to gain an audience's trust (Baumlin 1994, "Introduction", p. xvi).

Unsurprisingly, this version of Aristotle appealed to theorists of the 1970s and 80s-the high point of poststructuralism in the American academy. ${ }^{32}$ With the recent ascendance of cultural studies (within composition pedagogy especially), theorists have sought to reinterpret the Rhetoric as a document in cultural/communal consensus-building and positionality. A "rhetorical community," as Susan Miller describes it, delineates "an ethos-a sensus communis and a locus communis-a place where interlocutors abide, about which they contest, and from which they draw appeals" (Miller 2007, Trust, p. 198):

Those who dwell within a rhetorical community acquire their character as rhetorical participants from it, as it educates and socializes them. The community does this at least in part by supplying the Aristotelian components of ethos—the judgment (phronesis), values (arete), and feelings (eunoia) that make a rhetor persuasive to other members of the community. (Miller 2007, Trust, p. 198)

Thus, "Aristotle's Rhetoric presupposes a social context" (LeFevre 1987, Invention, p. 45). Karen Burke LeFevre adds that the "three kinds of proofs ... presuppose the existence of others who may or may not accept certain proofs" (Invention, p. 45). She continues:

Perhaps most pertinent to a social perspective is Aristotle's concept of ethos ... [which] arises from the relationship between the individual and the community. "Ethos," says Karlyn Kohrs Campbell, "does not refer to your peculiarities as an individual but to the ways in which you reflect the characteristics and qualities that are valued by your culture or group. In Aristotle's view, ethos cannot exist in isolation; by definition it requires possible or actual others ... . [I]n fact, the Greek meaning for "ethos" as "a habitual gathering place" calls forth an image of people coming together .... Ethos, we might say, appears in that socially created space, in the "between," the point of intersection between speaker or writer and listener or reader." (LeFevre 1987, Invention, pp. 45-46)

It's the notion of "the 'between'" as a site of dialogic/dialectical engagement that intrigues us. ${ }^{33}$ Citing LeFevre, Susan C. Jarratt and Nedra Reynolds argue similarly:

31 There's no need to mince words on the amorality of rhetoric: as a two-edged sword used for attack and defense on either side of any issue, rhetoric offers no guarantee as to the ethics of its practitioners. Weapons of any sort-and rhetoric has often been described in militaristic terms-inhabit a neutral territory, being neither good nor bad in themselves. The judgment rests not on the instrument but on the agent. (Such is the NRA's basic claim: guns don't kill people, people kill people-with guns.)Then again, Goffman bases social interaction generally on the concept of "appearance management," which drives a wedge between "successful" and "sincere" performance:

[W]hile persons usually are what they appear to be, appearances still could have been managed. There is, then, a statistical relation between appearances and reality, not an intrinsic or necessary one .... Some performances are carried off successfully with complete dishonesty, others with complete honesty; but for performances in general neither of these extremes is essential, and neither, perhaps, is dramaturgically advisable. The implication here is that honest, sincere, serious performance is less firmly connected to the solid world that one might first assume. (Goffman 1959, Presentation, p. 71)

32 Composition theorists might also remember the expressivist pedagogies of the 1960s and 70s. To classicists, cognitivists, and social-constructionists, these may have seemed a mere "fad," though they built upon postwar philosophies of existentialism. (Were this survey meant to be comprehensive, we would add the behaviorist models of self that undergird the rhetorical pedagogies of cognitivism.)

33 What LeFevre claims for ethos, Mikhail Bakhtin (1895-1975) claims for language generally: "As a living, socio-ideological concrete thing ... language, for the individual consciousness, lies on the borderline between oneself and the other," making "the word in language" half one's own and "half someone else's" (Bakhtin 1981, Dialogic, p. 29). Though Valentin 
[T]he rhetorical practice of êthos marks the position of the self, to the admittedly limited extent that it can be articulated by the author, making no claim that this speaking self is completely known or stable. Appearing "in that socially constructed space, in the "between," the point of intersection between speaker or writer and listener or reader" (LeFevre 45-46), ethos is the admission of a standpoint, with the understanding that other standpoints exist and that they change over time. (Jarratt and Reynolds 1994, "Splitting Image", p. 53)

In their typography, Jarratt and Reynolds follow Corts (1968, “Derivation", p. 201) in "clarify[ing] the 'confusion' between an older [Homeric] word ethos (spelled with a Greek epsilon), meaning 'custom' or 'habit,' and the newer [Aristotelian] êthos (spelled with an eta), meaning 'character'" (Jarratt and Reynolds 1994, "Splitting Image", p. 42). With this distinction, we are brought to Heidegger, whose discussion of ethos as "haunt" has opened new spaces for contemporary theory-spaces where collectivities and group identities are fashioned and gather together.

\section{Heidegger: Ethos as "Haunt"}

In a scene from Book 6 of Homer's Iliad, Paris is described:

Even as when a stalled horse that has fed his fill at the manger breaketh his halter and runneth stamping over the plain ... on high doth he hold his head, ... and as he glorieth in his splendour, his knees nimbly bear him to the haunts [ $\ddot{\eta} \theta \varepsilon \alpha]$ and pastures of mares; even so Paris, son of Priam, strode down from high Pergamus, all gleaming in his armour like the shining sun, laughing for glee, and his swift feet bare him on. (6.506-16)

Within this Homeric simile, we find the earliest literary etymon of ethos: the $\ddot{\eta} \theta \varepsilon \alpha i \pi \pi \omega \nu$ or “habitats of horses" (Homer 1924, Iliad, 6.511). In his "Letter on Humanism" (Heidegger 1949), Martin Heidegger (1889-1976) is arguably first to uncover, within $\eta^{\gamma} \theta 0 \varsigma$ or ethos-as-character, the more primal $\ddot{\eta} \theta \varepsilon \alpha$ or ethos-as-dwelling place. His reading of Heraclitus (c. 535-475 BCE) does not cite the Iliad, though the Homeric $\ddot{\eta} \theta \varepsilon \alpha$ lies in the background:

The saying of Heraclitus (Fragment 119) goes: $\tilde{\eta} \theta 0 \varsigma \dot{\alpha} \nu \theta \rho \dot{\omega} \pi \omega \delta \alpha i \mu \omega v$. This is usually translated, "A man's character is his daimon." This translation thinks in a modern way, not a Greek one. $\tilde{\eta} \theta 0 \varsigma$ means abode, dwelling place. The word names the open region in which the human being dwells. The open region of his abode allows what pertains to the essence of the human being ... to appear. According to Heraclitus's phrase this [essence] is $\delta \alpha i \mu \omega v$, the god. The fragment says, the human being dwells, insofar as he is a human being, in the nearness of god. (Heidegger 1949, "Letter", p. 269)

From the Homeric "habitats of horses," Heidegger carries ethos into the "abodes of men," where Being is revealed, known, cared for, and preserved. ${ }^{34}$

N. Voloshinov (1895-1936) reduces "the inner psyche" to an effect of language, nonetheless he, too, describes selfhood as a transaction occurring in a "between" space:

The reality of the inner psyche is the same reality as that of the sign. Outside the material of signs there is no psyche.... By its very existential nature, the subjective psyche is to be localized somewhere between the organism and the outside world, on the borderline separating these two spheres of reality. It is here that an encounter between the organism and the outside world takes place, but the encounter is not a physical one: the organism and the outside world meet here in the sign. (Voloshinov 1986, Marxism, p. 26; emphasis in original)

Like the "subjective psyche" that it seeks to express, ethos exists "somewhere between the organism and the outside world" (Voloshinov 1986, Marxism, p. 26) - this "somewhere between" being "none other than a discourse whose language is in part one's own but in equal part a possession of one's history and culture" (Baumlin 2001, "Ethos", p. 273).

34 We should acknowledge that the Heraclitean passage is never mentioned in Aristotle's Rhetoric. Its presence, thus, is allusive and implicit at best. So notes Craig R. Smith: 
Let us confess up front that we can't unpack Heidegger's prose in any way that does justice to his phenomenology. Nor can we turn a blind eye to Heidegger's unapologetic Nazism. ${ }^{35}$ It seems a paradox that his ethic of Sorge or "care" preceded the "care ethic" of Carol Gilligan (1982) and Nel Noddings (1984) (among other feminist moral theorists) by several decades—and that his ethotic theory would be invoked in discussions promoting multiculturalism. Despite its author's wounded reputation, the "Letter on Humanism" has something to teach us about contemporary ethos.

Returning to the passage above, the Heraclitean translation is "modern" in that its world view is, paradoxically, pre-Socratic: that is, it invokes human being as an embodied existence in-the-world, and not as an abstraction belonging to metaphysics. The Greek daimon has any number of meanings, including "lesser god," soul, and destiny: indeed, "character is fate" remains the most obvious (and accessible) Heraclitean paraphrase. Though Heidegger wants to invoke a sense of mystery and unfamiliarity (Unheimlichkeit) in the paraphrase, we follow Michael J. Hyde in emphasizing its revelation of the Truth of Being: "The human being," writes Hyde, "is called to be true to its essential character (ethos). We are the opening of a dwelling place where the truth of what is-be it a stone, tree, eagle, ourselves, or whatever-can be taken to heart, appreciated, and cared for" (Hyde 2004, "Introduction", p. xx; emphasis in original). Thus Heidegger holds out the hope that there "is" an ontic Truth of Being that precedes and transcends all ideology or "social construction." As Dasein or Being-in-the-world, we are called to bear witness to the Truth of Being and to dwell within that space wherein our humanness lies. In this unified life-world—-the Heideggerian "fourfold" (Geviert) of earth, sky, mortals, and divinities-we are called by conscience to serve the world as witness, companion, and caretaker. ${ }^{36}$

We have labored to make this point, since Heideggerian philosophy undergirds any modern claim on behalf of ontology: that is, on behalf of the Truth of Being. Similarly, Heidegger underwrites a theory of self-authenticating ethos that reveals itself-and expresses, indeed celebrates itself epideictically—rather than "merely" constructs itself via language. ${ }^{37}$ Finally, the Heideggerian

[A]t no place does Aristotle see ethos as a dwelling in the sense that Heraclitus used the term.... The first place that Aristotle acknowledges in the Rhetoric is the Areopagus, the high court, where, of course, ethos was enormously important .... For Aristotle, it is a given: everyone has ethos whether it be noble or ignoble. Before one even speaks, that ethos has an ontological dimension because it emerges from the way one makes decisions, the way one lives on a day-to-day basis, the way one dwells. Those decisions are informed by one's values, one's practical wisdom, and one's goodwill, all of which are addressed in detail by Aristotle. Thus Aristotle assumes the knowledge of the Athenian fore-structure of ethos as a dwelling place and then reformulates the notion of dwelling place to present a rhetorical understanding of ethos. (Smith 2004, “Ethos", p. 2)

35 Uncompromising in his criticism, David H. Hirsch turns the Heideggerian proposition that thought "shows-forth the thinker" against its author: "It is now clear that Heidegger's attraction to National Socialism and his extended membership in the Nazi party were consistent with, rather than aberrant to, his thinking. By the same token, it is possible to contemplate connections between national Socialism and the post-Auschwitz perpetuation of Heidegger-inspired antihumanist theories in the guise of what has come to be called postmodernism" (Hirsch 1991, Deconstruction, pp. 255-56).

We don't know what to say, other than that Heidegger's Nazism is a reprehensible ethical failure. We wish we could posit two Heideggers, distinguishing the one who joined the German National Socialist Party in 1933 from the one who survived the war to write his "Letter on Humanism" in 1949. But of course, we can't.

36 Again, we quote Hyde: "Existence calls, and for the sake of others and ourselves, we are obliged to respond in a responsible and thus rhetorically competent way. Something that is other than the self demands nothing less. The demand comes with acts of disclosure. With a showing-forth of all that there is" (Hyde 2004, "Introduction", p. xxi).

The human responsibility as caretaker introduces ecological themes into Heideggerian philosophy: "The basic character of dwelling," says Heidegger, "is to spare, to preserve. Mortals dwell in the way they preserve the fourfold in its essential being, its presencing ... . Mortals dwell in that they save the earth ... . To save the earth is more than to exploit it or even wear it out. Saving the earth does not master the earth and does not subjugate it" (Heidegger [1951] 1978, "Building", p. 328). Rather, "to spare and preserve means to take under our care, to look after the fourfold in its essence" (p. 329).

37 As Hyde notes (Hyde 2004, "Introduction", p. xxi), the conscientious or caring rhetor's task is "to disclose or show-forth (epi-deixis)" Being. Such rhetorical artistry, Hyde adds, "assumes an epideictic function" (p. xxi). We aim to expand upon this last insight: within traditions of "cultural and narrative ethos," the aims and strategies of epideictic rhetoric-a rhetoric, that is, of ceremonial occasion, celebration, and self-display - come to the fore. We argue, in fact, for the discursive confluence of ethos, expressivism, and epideixis. 
notion of human being as existential/ecological caretaker undergirds our argument on behalf of a commodious, iatrological rhetoric. Here, too, we draw on Hyde's reading of Heidegger:

We did not create the fundamental structure and workings of this primordial place and its attending call of conscience; rather, they are "givens,'" they come with the Being of existence, they are part of the essential character of human nature. We are creatures who dwell on this earth and who are thereby destined to hear and answer a call that, among other things, requires a capacity for practicing the art of rhetoric. The ontological structure of existence is such that we must learn to dwell rhetorically.... The call of human being, of conscience, calls on us to be rhetorical architects whose symbolic constructions both create and invite others into a place where they can dwell and feel at home ... . (Hyde 2004, "Introduction", p. xxi; emphasis in original)

Adding to this analysis, we call attention to a lesser-known text, Heidegger's lecture, "Building Dwelling Thinking" (Heidegger [1951] 1978), which helps gloss his Heraclitean discussion. Having declared that "building (bauen) aims at dwelling (wohnen)" ("Building", p. 326), Heidegger proceeds to play with the German etymology, much as he had done with the Greek:

We do not dwell because we have built, but we build and have built because we dwell, that is, because we are dwellers. But in what does the essence of dwelling consist? Let us listen once more to what language says to us. The old Saxon wuon, the Gothic wunian, like the old word bauen, mean to remain, to stay in a place. But the Gothic wunian says more distinctly how this remaining is experienced. Wunian means to be at peace, to be brought to peace, to remain in peace. The word for peace, Friede, means the free, das Frye; and fry means preserved from harm and ... safeguarded. To free actually means to spare .... [Sparing] takes place when we leave something beforehand in its own essence, when we return it specifically to its essential being, when we "free" it in the proper sense of the word into a preserve of peace. To dwell, to be set at peace, means to remain at peace within the free, the preserve, the free sphere that safeguards each thing in its essence. The fundamental character of dwelling is this sparing. (Heidegger [1951] 1978, "Building", pp. 326-27; emphasis in original)

We do not see how this exploration of the German Wohnen-as-dwelling, delivered several years after Heidegger's "Letter on Humanism," can be kept insulated from the Greek $\eta^{z} \theta 0 \varsigma$-as-dwelling. Surely his lecture, "Building Dwelling Thinking," helps us read the more famous, more influential "Letter."

The Heideggerian model appeals to us for many reasons, not least of which is the ethical claims that it makes upon the speaker. ${ }^{38}$ One speaks not simply to declare one's "dwelling place," nor simply to share that dwelling, but also to care for it. Situated within a self/other dialectic, the act of self-expression becomes an invitation to dwell with others, "to open a space," by means of language, where self and other "can dwell and feel at home" (Hyde 2004, "Introduction", p. xxi). It is an invitation to hospitality.

As an expansion upon Aristotelian eunoia, it's the Heideggerian attitude of caring that leads us into a new "New Rhetoric," one suited to the pluralist, post-Enlightenment, multiculturalist discourse of our age. It should be noted, however, that Heidegger does not acknowledge "cultural difference" within his discussion of $\ddot{\eta} \theta \varepsilon \alpha$ or "haunts." For Heidegger, the ethos-as-dwelling is Being-as opposed to the "beings" that constitute nations, ethnicities, classes, and occupations. Hence, any discussion of

38 Like Heidegger, Ludwig Wittgenstein (1889-1951) explores the interrelationships among self, world, and language. For future study, we'd suggest putting the twentieth century's two great philosophers into a dialogue over ethics and ethos: in what ways does Wittgenstein's philosophy of language-particularly his posthumous Philosophical Investigations (Wittgenstein 1953) reinforce, complicate, or question the Heideggerian model presented above? (As a starting point, we'd recommend Paul M. Livingston's (2015) essay, “Wittengenstein Reads Heidegger, Heidegger reads Wittgenstein: Thinking, Language Bounding World.") 
positionality in the Heideggerian "haunt" is a misprision, though useful for our purposes. We have one more component to add to our model; we find it back in Aristotle, though not in his Rhetoric.

But, first, we must return to Homer.

\section{From Ethos to Mythos: The Case for Storytelling}

In Book 9 of the Odyssey, having enjoyed the Lord Alcinous's hospitality, Odysseus yields to the request that he give his name and tell his story:

First now will I tell my name, that ye, too, may know it, and that I hereafter ... may be your host, though I dwell in a home that is afar. I am Odysseus, son of Laertes, who am known among men for all manner of wiles, and my fame reaches unto heaven. But I dwell in clear-seen Ithaca, ... a rugged isle, but a good nurse of young men; and for myself no other thing can I see sweeter than one's own land. Of a truth Calypso, the beautiful goddess, sought to keep me by her ... and in like manner Circe would fain have held me back in her halls ... but they could never persuade the heart within my breast. So true is it that naught is sweeter than a man's own land and his parents, even though it be in a rich house that he dwells afar in a foreign land ... . But come, let me tell thee also of my woeful home-coming, which Zeus laid upon me as I came from Troy .... . (Homer 1919, Odyssey, 9.16-38)

In such a passage, Homer models for us the hospitable aims of a commodious discourse. If asked, "Who are you?" one's answer unfolds in narrative: "I was born in _ _, "I have lived in _-," "I went to school at __, "I teach at __, "I am married to _ , , and so on. Whether revealed or constructed, self-image unfolds or "emerges," as Corder puts it, within structures of language: specifically, within stories. These are shared by individuals within culture: that is, stories translate actions, events, and experiences into sharable meaning inviting response. Such, indeed, is a reigning premise of our essay and of the greater collection, Histories of Ethos: that our stories, whether individual or collective, are primary bearers of ethos in the twenty-first century.

In emphasizing the role of biography—that is, of "life-writing" —in self-identity, Anthony Giddens (1938-) carries ethos into the realms of storytelling: "self-identity," he writes, "is not a distinctive trait, or even a collection of traits, possessed by the individual. It is the self as reflexively understood by the person in terms of her or his biography" (Giddens 1991, Modernity, p. 53; emphasis added). We quoted Giddens in an epigraph, but we give the passage here in full:

The existential question of self-identity is bound up with the fragile nature of the biography which the individual "supplies" about herself. A person's identity is not to be found in behavior, nor-important though this is-in the reactions of others, but in the capacity to keep a particular narrative going. The individual's biography, if she is to maintain a regular interaction with others in the day-to-day world, cannot be wholly fictive. It must continually integrate events which occur in the external world, and sort them into the ongoing "story" about the self. (Giddens 1991, Modernity, p. 54)

Understanding Giddens, we are reminded that "story" (mythos) is a subject of Aristotle's Poetics. In his Rhetoric, Aristotle discusses ethopoeia as a mode of "stylistic ethos" (Baumlin 2001, "Ethos", p. 267). ${ }^{39}$ But we can go further and describe a mode of "narrative ethos" that treats mythos as one of

39 Focused on style, Book 3 of the Rhetoric contains a group of passages pertaining to character-delineation, of which the following (3.16.8-9) is representative:

The narration ought to be indicative of character $[\dot{\eta} \theta \iota \kappa \eta]$. This will be so if we know what makes character [ $[\tilde{\eta} \theta 0 \varsigma]$. One way, certainly, is to make deliberate choice [ $\pi \rho \circ \alpha i \rho \varepsilon \sigma \iota \zeta]$ clear: what the character is on the basis of what sort of deliberate choice [has been made].... Other ethical indications are attributes of each character, for example, that someone walks away while talking; for this makes his arrogance and his rudeness of character clear. (1417a-b) 
four pisteis or "proofs," functioning rhetorically and contributing to the self-expressive aim of ethical/ ethotic discourse. ${ }^{40}$

Rhetoric consists of more than persuasion (if, by persuasion, one aims at compelling an audience's consent to a specific course of action, policy, or point of view). Aristotle acknowledges this fact: in addition to deliberative rhetoric — the "art of persuasion" properly so-called-his Rhetoric describes forensics (a rhetoric of accusation and defense) and epideixis (a rhetoric of ceremonial occasion and artistic self-display). It is in self-display that ethos, epideixis, and mythos coalesce. By declaring narrative-mythos, not logos-the foundational activity of human social discourse, we seek to ground postmodern ethos in storytelling. There are more components to ethos than one's storytelling; the Rhetoric convinces us of that. But story is the glue that holds them all together.

Action, agency, time, and place - the stuff of narrative—are ethotic building blocks. A singular moment in time, often one of trauma or tragedy, can come to dominate the narrative-hence, the identity — of a person, or of a people. When a specific marker of identity is embedded within an action or event-in-time, one's storytelling is reshaped accordingly: a speaker can affirm and commemorate, defend and advocate, repair and seek justice, or seek transcendence (seek, that is, to move beyond the self-defining marker). A psychosocial model of ethos as "self in process" assumes that ethos can, in fact, evolve or change over time. In this sense, ethotic discourse rests in telling and retelling, in making appeals to the future as well as in acknowledging the past. ${ }^{41}$

Let us revisit the Corderian definition, "character as it emerges in language" (Corder 1978, "Varieties", p. 2). Rendered coherent through the conventions and structures of narrative, a storyline emerges: within the history of its telling, the personalized self-image—call it "the self"—comes into view. The self-as-narrated unfolds within "thematic patterns" of habit: choices of lifestyle, occupation, dwelling, attitudes, affects, addictions. Markers of identity derive from culture, demographics, ethnicity, and a gendering of the body. Behaviors and speech patterns replicate by reenacting life-choices and attitudes: one calls oneself the same name (and the same nicknames among friends); one goes to bed and wakes up in the same place; one goes to work at the same job in the same place at the same time of day (and returns to the same home in the same place at the same time of day); and, one yields to the same prejudices, the same affects and attitudes and desires (and addictions), all on a daily basis. By such repetitions, the individual becomes scripted within a storyline that translates the

40 For a discussion of mythos as a fourth "proof," see (Baumlin and Baumlin 1994, "On the Psychology of thePisteis", p. 100). Part of the art of storytelling is self-reflexive, in that it focuses on the character of the storyteller. So Liesbeth Korthals Altes notes with respect to narrative fiction:

In fact, signaling and deciphering sincerity, deception, or irony and classifying speakers regarding their authority, reliability, and expertise have been the core business of storytelling since humankind's very first stories. Whole literary genres, such as satire or the engage novel, are defined by their assertion mode and ethos, as are the types of literary authors, narrators, and characters, from the ironist and unreliable Picaros ... to the doctus, prophet, or gadfly .... Thus literature spells out codes of conduct and exemplary paths for ethos projection and attribution, helping to shape, transmit, and question culture-bound folk semiotics and hermeneutics of ethos. (Altes 2014, Ethos and Narrative, p. 7)

41 Respecting our collection, perhaps a more hopeful title would be Histories, and Futures, of Ethos. Each species of rhetoric, Aristotle tells us (Rhetoric 1.3.4), "has its own "time'" (1358b), though epideixis spills over into past, present, and future. Eugene Garver explains: "When Aristotle introduces the three kinds of rhetoric in 1.3, he says that deliberation concerns the future, judicial rhetoric the past, but he does not say that epideixis is about the present ... . Later in the chapter, he does claim that each kind of rhetoric has a specially appropriate time, but again makes an exception for epideixis" (Garver 1994, Aristotle's Rhetoric, p. 71). As Garver translates the passage (Rhetoric 1.3.4),

[T] o epideixis most appropriately [belongs] the present, for it is the existing condition of things that all those who praise or blame have in view. It is not uncommon, however, for epideictic speakers to avail themselves of other times, of the past by way of recalling it, or of the future by way of anticipating it (1358b). (Garver 1994, Aristotle's Rhetoric, pp. 71-72) 
singularity of personhood into character and community. In effect, one becomes the protagonist of one's own mythos.

Character can be understood as the "personal styles" of an individual whose life-narrative is rendered interpretable and, indeed, predictable through its replicable consistency of behavior. (This consistency, this predictability, is a working definition of sanity: the ability to wake up the next day and be the same person ... ) In conforming to "a character," the individual works within a culture-bound set of typologies, social roles, rules, and responsibilities. In practice, a dialectic arises between personhood and character-type, in that a shift on one side causes shifts on the other (and the postmodern agent is, as Giddens notes, defined by choice-in-lifestyle: one day, she may choose not to go home). ${ }^{42}$ The point is that our personal stories have meaning within patterned life-histories that are historically- and culturally-conditioned.

Following a psychoanalytic model of identity-formation, we presume that specific life-events-traumas for the most part-play constitutive roles in identity-formation. The abused spouse lives within an event and a narrative of that event: the abuse becomes thematic within that person's self-image and life-story. Not all identity-forming events are traumatic: love, an act of heroism, an occupational or material or intellectual or social success, sudden fame, a mystic experience: any and all such life-events can become the "identity theme" (Holland 2011, The I, p. 51) within an individual's storyline.

A further corollary to postclassical ethos (indebted both to psychoanalytic praxis and to modern feminism) is the need to tell one's story, particularly those aspects that bear wounds. Indeed, the highest aim of ethotic discourse is, or ought to be, to share one's story; and, with respect to one's functioning as audience, the highest corresponding aim is to bear witness to that other's story. Self-knowledge (in both the Socratic and the Freudian sense) and self-expression or display (in the Gusdorfian/Corderian sense) are ethical urgencies of an ethocentric (as opposed to logocentric) discourse.

A narrative theory of ethos is postclassical for a further reason, in that it replaces the classical model of rhetorical agon or competition with a therapeutic model. The highest aim of discourse is not to persuade, compel, or "gain compliance," but to recognize, accommodate, and heal-to heal oneself and one's community through mutual understanding, consensus, equity, mutuality. Thomas Szasz (1920-2012) has called this an iatrology, a speaking of "healing words" (Szasz 1978, Myth, p. 29).

Following Heidegger, we hold to the possibility of a stable ontology or Truth (taking "truth," simply, to mean "what is," irrespective of whether the human creature can know it or speak it adequately); still, as an expression of our Heideggerian (and feminist) commitments, we assert that any "truth" lacking in hospitality—or, more forcefully, in caring, equity, understanding, increased freedom, dignity, and personal fulfilment-is likely no more than oppression. Some years ago, Corder made similar claims in an essay, "Argument as Emergence, Rhetoric as Love." (If the word "love" embarrasses us intellectually, then let's replace it with "health," or with "hospitality," or with "community," or with "equity," or with "dignity," or with "freedom," or with "justice." Any of these value-terms will do when harnessed to an ethotic, iatrological rhetoric.) He writes:

42 "Lifestyle," writes Giddens, "is not a term which has much applicability to traditional cultures, because it implies choice within plurality of possible options, and is 'adopted' rather than 'handed down'" (Giddens 1991, Modernity, p. 81). He continues:

Lifestyles are routinized practices, the routines incorporated into habits of dress, eating, modes of acting and favored milieux for encountering others; but the routines followed are reflexively open to change in the light of the mobile nature of self-identity. Each of the small decisions a person makes every day ... are decisions not only about how to act but who to be. The more post-traditional the settings in which an individual moves, the more lifestyle concerns the very core of self-identity, its making and remaking. (Giddens 1991, Modernity, p. 81)

Going beyond Gidden's analysis, we would argue that the ongoing enculturation of most lifestyle choices impacts "character," even in postmodernism. 
Let there be no mistake: a contending narrative, that is, an argument of genuine consequence because it confronts one life with another, is a threat, whether it is another's narrative becoming argument impinging upon or thundering into ours, or our own, impinging upon the other's. (Corder 1985, “Argument", p. 19)

The "threat" posed by another's "contending narrative" arises from the positionality of oppressive cultural and societal structures; and it is these structures that return us, yet again, to Aristotle.

The classical-Aristotelian model of rhetoric-as-persuasion must have an ethotic component, in that any significant change- of mind or emotion, in action or attitude-will impact an audience's habits of behavior and, correspondingly, its self-concept. Still, we question the extent to which a person's self-concept (with its concomitant behaviors, habits, affects, addictions) can change by means of storytelling. ${ }^{43}$ We presume that the ability to change one's story can change the storyteller. Following Alcorn (1994, "Self-Structure", p. 12), we assume that self-concepts, like the stories that undergird them, require some stability (that is, some predictability and replicability in behavior); but, while self-concepts are self-protective and inherently resistant to change, they are subject, nonetheless, to retelling. Whether the story changes the storyteller or the storyteller changes the story, the essential unity of the self, the self-reflexive self-concept, and the self-revealing/ self-constructing story is foundational to an ethotic, iatrological rhetoric.

The iatrological model is rhetorical in structure, being dyadic. ${ }^{44}$ Storytellers need audiences: even when one speaks to oneself, one does so as "self to an other." We are selves in community; our stories have meaning within the broader cultural narratives to which they largely conform. A self-concept fulfills itself as ethos when it is "outed," that is, enacted or performed "in public." The notion of an ethos separable from the co-presence of an other-an audience-witness-is an absurdity. Ethos is fulfilled in the presence of the other. We are compelled to tell our stories in a world of storytellers. Within a sharing community, ideally, we take turns speaking and listening, bearing witness to one

43 As Marshall W. Alcorn Jr. notes, poststructuralist theory describes "an overly weak self," composed "of collected social discourses" and "conform[ing] effortlessly to textual influences" (Alcorn 1994, "Self-Structure", p. 6). "This view of the self," Alcorn adds, "helps us appreciate the social determination of selfhood, but it implies that the self, once formed, has no organized, 'characteristic' inner structure" (p. 6). As if fusing insights from Freud, Bakhtin, and Voloshinov, Alcorn offers an important corrective to the poststructuralist effacement of self:

A particular self is not an infinitely changing collection of voices housed within a biological organism. It is a relatively stable organization of voices. We need not adopt the various models of self-organization advocated by psychoanalysis, but as rhetoricians, we should acknowledge that the self has a relatively stable inner organization. (Alcorn 1994, "Self-Structure", p. 12)

Rhetoric, thus conceptualized, "might be defined as a well-focused and carefully crafted strategy for changing self-organization" (Alcorn 1994, "Self-Structure", p. 14). And, due to "the inner dynamics of self-division-the ability to liberate repressed voices, to activate self-conflict, to reshape the linguistic form of self-components" (p. 12) - the most potent mode of change comes as a mode of self-persuasion. As Alcorn notes, "Self-persuasion comes not from the outside, as an external authority goading people to accept certain values, but from the inside, as an internal voice (both an agent and an expression of self-change) reorganizing relationships among self-components" (p. 26). We find ourselves very much in agreement with his model of self and its implications, both for ethos and for rhetoric generally.

44 "For discourse," As James S. Baumlin and Peter Scisco write, "is dyadic-a rhetorical two-way street between speakers and audiences-and rhetoric is responsive in its intended effects: speakers address audiences in order to gain their favor and assent" (Baumlin and Scisco 2018, "Ethos", p. 201; emphasis in original). They continue:

Until an audience responds or complies in some manner, the dyadic structure of discourse remains unfulfilled. Hence, a "speaker" "speaks to" an audience in ways that "reveal"—or, alternatively, construct-a credible character or image. Rarely do rhetors assume a passive audience: rather, audiences are presumed to collaborate in fashioning or affirming a speaker's ... image. There are further complications in accommodating one's intended audience. In seeking an audience's assent, a speaker must understand and appeal to that audience's own character: that is, to its values, its habits, its predispositions, its prejudices, its aspirations and idealized self-image. A premise of social psychology ... is that audiences tend to trust or "like" speakers who are "like them" in some way. A speaker's character may be "revealed" or "constructed," but it might also be projected, and an audience's projections of trust and reliance are likely to be unconscious in their workings. (Baumlin and Scisco 2018, “Ethos", p. 201) 
another. We share in the diversity of stories. Following Jean-François Lyotard (1924-1998), we might think of "community" itself as a sharing of "localized narratives" or petits récits. ${ }^{45}$ The same dynamics that define individual character arise in the creation and healthy maintenance of community.

As we've argued, community is premised in a sharing of stories. And here we face a problem explored by Michel Foucault, among other cultural critics: we dwell in worlds marked by an intersection of power and discourse. In a world of unequal distribution of power, ethos becomes an agon of competing texts. More than sharers or witnesses, people are cast as objects of control and "compliance." In this power-riven model, people not only compete for ethos (that is, for the right to "be seen" through/in their words); they lose ethos within opposing narratives, alienated by acts of naming: queer, radical Islamic terrorist, disabled, Mexican rapist, "animal," etc. Contemporary American political rhetoric plays out its "culture wars" with markers of identity/difference as its weapons and ethos as its battlefield.

While iatrology - a healing of self and community through an expressivist/epideictic rhetoric-remains a dream in our culturally, politically, economically fractured world, we can, nonetheless, take steps towards its realization. ${ }^{46}$ The first step in healing ourselves, individually and collectively, is to unleash the self-expressive power of our storytelling: in effect, to make an appeal in good faith for a witness, in order "to be seen" in our texts. As we look beyond the Western, Eurocentric-masculinist Enlightenment model, we discover alternative histories, epistemologies, logics, moral systems, sciences, medical practices, pharmacies, arts, rituals. We need to learn from them; at the least, we need to listen to them-or learn to listen. We cannot expect that the forces of hegemonic culture will hold back in their attempts at silencing alternative voices. Political campaigning will continue its attack ads, "controlling the narrative" by demonizing opponents. Even the academy plays its power games, policing credentials of those who "earn the right" to speak authoritatively (and reap the rewards therefrom).

In recent years, the academy has become more open to diversity, interdisciplinarity, and hybridized approaches/genres; but it, too, needs to learn greater humility and hospitality. The scholarly ethos pretends to impersonality, "universality," and rationalism. ${ }^{47}$ While caricaturing the modernist "model citizen," White's character sketch strikes very near the academician:

45 In The Postmodern Condition (Lyotard [1979] 1984), Lyotard offers petits récits as an antidote to the totalizing-oppressive "grand narratives" of modernism: "progress," "Enlightenment emancipation," Marxism, etc.

46 "Our time" is one "of fragmentation and isolation," as S. Michael Halloran observes, a time when ethos can succeed only by the degree to which a speaker "is willing and able to make his world open to the other," thus risking "self and world by a rigorous and open articulation of them in the presence of the other" (Halloran 1975, "On the End", pp. 627-28). Halloran wrote this in 1975. Our own time is one of fragmentation still, according to Mansfield:

Selfhood is now seen to be in a state of perpetual crisis in the modern West. Alienated intellectuals and suicidal youth; culture wars and volatile markets; endless addictions to food, work, alcohol and narcotics; sexual inadequacy and thrill killers-all feed into education and entertainment industries that keep the intensity of our selfhood perpetually on the boil, nagging and unsettling, but also inspiring and thrilling us with mystery, fear and pleasure. It is this ambivalence and ambiguity - the intensification of the self as the key site of human experience and its increasing sense of internal fragmentation and chaos-that the twentieth century's theorists of subjectivity have tried to deal with. (Mansfield 2000, Subjectivity, Kindle ed., pp. 108-14)

47 In the following passage, Carolyn R. Miller unmasks the logocentric assumptions lurking in the discourse of science. We should ask: To what extent do her observations hold for scholarship in the humanities?

[O]ne of the primary conclusions of recent work in the rhetoric of science and technology is that this rhetorical style of impersonality, in which facts "speak for themselves," is itself an appeal that universalizes results originating in particularity; the scientist must seem fungible, so that her results could have been —and might be-achieved by anyone. This appeal is an ethos that denies the importance of ethos. The technical ethos must be informed but impartial, authoritative but self-effacing. One of the major strategies for achieving this delicate balance is the transformation of ethos into logos. (Miller 1994, "Expertise", p. 203) 
He is conceived as disengaged from his social background and oriented toward mastery of the world that confronts him; nevertheless, he can discover, by the light of reason, universally applicable principles of justice, found in some foundationalist account of God, nature, progress, or human communication that can become the basis of political consensus with other individuals. (White 2009, Ethos, pp. 33-34; emphasis in original) ${ }^{48}$

As scholars, we should make a habit of positioning and declaring ourselves within our writing. For a few years after the turn of the new century, a "scholarship of the personal" was promoted (in composition journals primarily), an approach allowing for reflection upon the processes as well as the products of one's research, often within a narrative frame. Combining strategies of the "traditional" scholarly and personal essays, this "scholarship of the personal" is the sort of hybridization needed rhetorically/ethotically today. ${ }^{49}$

Fortunately, we have companions in this call for a "return of the human" to the humanities. In his recent work, Mikhail Epstein practices precisely the sort of inventive, genre-bending "performative discourse" (Epstein 2012, Transformative, p. 19) described above. His Transformative Humanities: A Manifesto (2012) diagnoses the problem: with the ascendance of poststructuralism, the humanities "stopped being human studies and became textual studies. No one now seems to expect anything from the humanities except readings and re-readings, and, first and foremost, criticism rather than creativity and suspicion rather than imagination. As a result, the humanities are no longer focusing on human self-reflection and self-transformation" (Epstein 2012, Transformative, p. 2). Indeed, it's been a long time since the humanities mattered socially or politically. If we who teach within the humanities are to reclaim a voice in public affairs-if we are "to be seen and heard," in the manner described in this present essay—then we need a purpose beyond "mere theory."

Epstein reminds us what that purpose is, and it's expressive at its core. It's not in the object-world of the sciences that our proper studies lie. ${ }^{50}$ In fact, our task lies not in study so much as in creation-in the creation, specifically, of our "humanness," as Epstein declares:

The crucial distinction between the humanities and sciences is that in the humanities the subject and the object of the study coincide; in the humanities, humans are studied by humans and for humans. Therefore, to study the human being also means to create humanness itself: every act of the description of a human is, by the same token, an event of one's self-construction. In a wholly practical sense, the humanities create the human, as human beings are transformed by the study of literature, art, languages, history and philosophy: the humanities humanize. (Epstein 2012, Transformative, p. 7)

48 White adds, "this complex of characteristics ... has been the target of a variety of twentieth-century thinkers from Heidegger to feminism, from Carl Schmitt to Foucault and postmodernism, from Horkheimer and Adorno to Charles Taylor" (White 2009, Ethos, p. 34). It's time that the academy were weaned off of this elitist self-image.

49 We refer readers to volume 64.1 of College English (2001), with its focus on "personal writing." In a later volume (2003), Jane E. Hindman lists several of "the rhetorical moves and genres" associated with "'the personal' in scholarship" (Hindman 2003, “Thoughts", p. 38):

... a specific, individual positioning of the researcher and/or the subjects of a qualitative study; an instance of "outing" oneself by revealing religious, sexual, ethnic, racial, or economic affiliations; an autobiographical account, a memoir; a hybrid genre of theory and autobiography; an embodied writing that examines the institutional origins of individual affect and taste; a reader's individual decision how to consume and circulate texts. (Hindman 2003, “Thoughts", p. 38)

For a sample of this approach, see Craig A. Meyer's essay, "From Wounded Knee to Sacred Circles: Oglala Lakota Ethos as 'Haunt' and 'Wound,'”' included in this collection.

50 In the process of demystifying the sciences through the humanities, "humans do not so much discover something in the world of objects as build their very subjectivity by way of self-description and self-projection" (Epstein 2012, Transformative, p. 8). Playing with the title of Thomas Nagel's well-known essay, "What is it like to be a bat?," Epstein writes, "the question itself appears to be the answer to another, more essential question: 'What is it like to be a human?' To be a human means to emerge out of self-containment and immerse oneself into the being of the other, as it were one's own. To be human means to ask what it is like to be a bat" (Epstein 2012, Transformative, p. 215; emphasis added). 
The essays gathered in Histories of Ethos seek to be true to this humanizing task. But the same qualification holds for Epstein as for Heidegger: being "clothed" in culture, our humanness needs to be seen in its diversity.

As for the politics of hegemonic culture, we ask: Who wields the skeptron? Who enjoys "the right to speak," to be heard? By what means can an individual or group assert that right? Must an oppressed minority flatter the "dominant voice" by mimicry or ventriloquism, by kowtowing to the dominant discourse and its rituals of authority? ${ }^{51}$ Must self-expression-the ultimate ethotic act, the act of speaking "to be seen" - be an act of defiance? The \#MeToo movement in America today is more than an appeal for justice: it is a combining of individual voices into an ethos expressive of the victim who will remain silent no more. And we are its witness. Surely the \#MeToo movement is iatrological, in that the women who are speaking out seek freedom and redress from trauma and oppression. They are "being seen" in the telling of their story; and, yes, there are patterns to their story. In response to their revelations, American society is learning to tell its own story differently. In time, perhaps, we will be healed of this sort of institutionalized violence-or at least, we will be cured of the "blindness" that tolerates sexual exploitation, among other modes of social, cultural, political, economic oppression.

We enlarge our ethos when we learn to speak differently of ourselves and of others, when we repudiate acts of silencing, when we offer ourselves as witnesses, when we create community by means of shared stories. Ethos is invested in every aspect of our speaking, listening, and responding. Let the Enlightenment "Age of Reason"- the epoch of logocentrism—pass; let ours be an Age of Ethos. Let us aim to make our discourse caring, accommodating, epideictic, iatrological, inventive, and personal.

\section{Conclusions}

In this introduction to Histories of Ethos, we have made a series of claims that individual essays will put to the test. Some will explore the "cultural dress," some the "modes of address," by means of which individuals situate themselves within communities in place and time. Competing versions of ethos, both in theory and in praxis, will be applied. ${ }^{52}$ The role of narrative in identity- formation-both individually and culturally-will be a recurring motif. And, while individual essays might explore only a portion of the spacious field of ethos within any culture at any time, we assume that any claim regarding ethos can be turned, dialectically, into its "enabling other." No premise or claim

51 On this subject, see Gayatri Chakravorty Spivak's essay, "Can the Subaltern Speak?" There's a further paradox in academic writing, in that we're encouraged to universalize and "depersonalize" our texts (in imitation of the sciences) even as we imitate-in effect, ventriloquize- the dominant theorists of our times. Ours is not so much a "cult of personality" as it is a "cult of vocabulary." In passing through the rituals of tenure/promotion, we are expected to master "academic literacy" in displaying an ability "to talk the current lit-crit talk" (Spellmeyer 1996, "After Theory", p. 909). But this mastery comes at the cost of an authenticating "personal style." What does "The Profession" teach us if not ventriloquism and impersonation, "demand[ing] that we remake ourselves in conformity with the project of the theorist" (Spellmeyer, "After Theory" 909; emphasis in original)? And "our reward for submitting" to this regimen, as Kurt Spellmeyer notes, "is seldom the renewal of connections to actual others, the people we happen to know in daily life. Don't we learn, instead, to serve an anonymous 'they'?" (Spellmeyer 1996, "After Theory", p. 909). Spellmeyer elaborates:

[T]hink, if you can stand it, about all the essays written ten or fifteen years ago that began with the claim to be writing "on the margin"; or of all the works today that call themselves "genealogies" ... . The writers of these works are not simply sycophants or opportunists. They write in this way is to become Derrida, to be become a second Foucault or a little Lacan. In the same way, Madonna's fans dress like walk and talk like her, and read books about her life. (Spellmeyer 1996, "After Theory", p. 909)

Granted, we've called our own essay a "genealogy." But we would like to think that we're using the Foucauldian vocabulary strategically and that the vocabulary is not using us. Spellmeyer's point pertains to ethos, though he does not use the term: "the time has come to acknowledge that academic literacy, at least as we've constructed it so far, is deeply complicit with the same culture of disembodiment that makes possible Elvis look-alikes and the stalking of the stars by their admirers" (Spellmeyer 1996, “After Theory”, p. 909).

52 We note, too, that some essays in our collection lean toward theory and analysis while others lean toward praxis and performance. We trust that the essays in Histories of Ethos can cross-reference each other, reducing their need to repeat the same theoretical underpinnings and assumptions: it may suffice that each consciously and conscientiously commits to a coherent theory/approach/vocabulary that can be found more fully articulated elsewhere in the collection and broader secondary literature. 
has been banished or disallowed from this collection. Hence, we affirm that ethos can be revealed or constructed; that it can pre-exist a speaker's discourse or be produced within (or by means of) discourse; that it can ally itself with, or it can subvert, logos or pathos. If it can heal and liberate, surely it can be used to harm. Self necessarily posits an other; identity implies difference. Narratives can be "fixed" within a culture's folk pathways and traditions; but these can also be revisited, reinterpreted, reshaped, retold. Ethos can be carried into new regions. With smart technologies, ethos enters the realm of the artificially-intelligent nonhuman — the cyborg. Even the "deep ecology" movement posits a "planetary ethos." 53

Let us summarize the aims and aspirations of our collection, as represented in this introduction. We might go so far as to declare the following a Manifesto-an intellectual call-to-action-for ethos in/for the twenty-first century. Once again, we seek the following:

to acknowledge the expressive core of discourse spoken or written, in ways that reaffirm and restore an epideictic function to ethos/rhetoric;

to demonstrate the positionality of discourse, whereby speakers and writers "out themselves" ethotically (that is, responsively and responsibly);

to explore ethos as a mode of cultural and embodied personal narrative;

to encourage an ethotic "scholarship of the personal," expressive of one's identification/participation with/in the subject of research;

to argue on behalf of an iatrological ethos/rhetoric based in empathy, care, healing (of the past) and liberation/empowerment (toward the future);

to foster interdisciplinarity in the study/exploration/performance of ethos, establishing a conversation among scholars across the humanities; and

to promote new versions and hybridizations of ethos/rhetoric.

We end with a selection of passages from Corder's "Argument as Emergence, Rhetoric as Love." We present them without commentary: they speak for themselves. And they speak for us, affirming several of our central themes. (Once again, if the word "love" embarrasses, put "hospitality" in its place.)

Each of us is a narrative. A good part of the time we can live comfortably adjacent to or across the way from other narratives. Our narratives can be congruent with other narratives, or untouched by other narratives. But sometimes another narrative impinges upon ours, or thunders around and down into our narratives. We can't build this other into our narratives without harm to the tales we have been telling. This other is a narrative in another world; it is disruptive, shocking, initially at least incomprehensible, and, as Carl Rogers has shown us, threatening.

When this happens, our narratives become indeed what they are perpetually becoming-arguments. The choosing we do to make our narratives (whether or not we are aware of the nature of our choosing) also makes our narratives into arguments. The narratives

53 Coined by Norwegian philosopher and naturalist, Arne Naess, "deep ecology" rejects "shallow environmentalism" for being "simply an extension of the anthropocentric Western paradigm" of land use, wherein "the reasons for preserving wilderness or biodiversity are inevitably couched in terms of human welfare" (Naess 1973, cited in (Keller, "Gleaning", p. 140). As David Keller notes, "shallow environmentalism falls short of valuing nonhumans apart from their use-value. Deep Ecology, in contrast, asserts that all organisms have intrinsic value. In this way Deep Ecology is fundamentally nonanthropocentric" (Keller 1997, "Gleaning", p. 140).

With his Gaia hypothesis, James Lovelock goes further in positing that the "whole earth," in all its living and non-living components, functions as if it were a single, unified, self-regulating organism-in effect, a self (Lovelock 1979, Gaia, pp. x-xii). By analogy with biological life, planetary ecology can be studied as a delicately balanced (and, with global warming, increasingly threatened) homeostasis. Clearly, the "deep ecology" movement is foreshadowed by Heidegger's ethics of "caring for" and "sparing" the "fourfold" of earth, sky, mortals, and divinities. (Also, much of American Indian ethos is definable by earth-sustaining attitudes and practices.) 
we tell (ourselves) create and define the worlds in which we hold our beliefs. Our narratives are the evidence we have of ourselves and of our convictions. Argument, then, is not something we make outside ourselves; argument is what we are. Each of us is an argument. We always live in, through, around, over, and under argument. All the choices we've made, accidentally or on purpose, in creating our histories/narratives have also made us arguments, or, I should go on to say, sets of congruent arguments, or in some instances, sets of conflicting arguments. (Corder 1985, p. 18)

Again:

Sometimes we turn away from other narratives. Sometimes we teach ourselves not to know that there are other narratives. Sometimes-probably all too seldom-we encounter another narrative and learn to change our own. Sometimes we lose our plot, and our convictions as well; since our convictions belong to our narratives, any strong interference with our narrative or sapping of its way of being will also interrupt or sap our convictions. Sometimes we go to war. Sometimes we sink into madness, totally unable to manage what our wit or judgment has shown us-a contending narrative that has force to it and charm and appeal and perhaps justice and beauty as well, a narrative compelling us to attention and toward belief that we cannot ultimately give, a contending narrative that shakes and cracks all foundations and promises to alter our identity, a narrative that would educate us to be wholly other than what we are. Any narrative exists in time; any narrative is made of the past, the present, and the future. We cannot without potential harm shift from the past of one narrative into the present and future of another, or from the past and present of one narrative into the future of another, or from the future we are narrating into a past that is not readily ours. How can we take that one chance I mentioned just now and learn to change when change is to be cherished? How can we expect another to change when we are ourselves that other's contending narrative? (Corder 1985, p. 19)

And again:

Argument is emergence toward the other. That requires a readiness to testify to an identity that is always emerging, a willingness to dramatize one's narrative in progress before the other; it calls for an untiring stretch toward the other, a reach toward enfolding the other. It is a risky revelation of the self, for the arguer is asking for an acknowledgment of his or her identity, is asking for witness from the other. In argument, the arguer must plunge on alone, with no assurance of welcome from the other, with no assurance whatever of unconditional positive regard from the other. In argument, the arguer must, with no assurance, go out, inviting the other to enter a world that the arguer tries to make commodious, inviting the other to emerge as well, but with no assurance of kind or even thoughtful response. How does this happen? Better, how can it happen?

It can happen if we learn to love before we disagree. (Corder 1985, p. 26)

And once more:

Rhetoric is love, and it must speak a commodious language, creating a world full of space and time that will hold our diversities. Most failures of communication result from some willful or inadvertent but unloving violation of the space and time we and others live in, and most of our speaking is tribal talk. But there is more to us than that. We can learn to speak a commodious language, and we can learn to hear a commodious language. (Corder 1985, pp. 31-32)

Funding: This research received no external funding.

Acknowledgments: We wish to thank the Humanities editors for supporting Histories of Ethos through its Knowledge Unlatched Initiative, which has made this collection free and available to all—truly "open access." 
Ours is an innovative collection, in that it invites contributors to perform ethos in ways that test and question the residually "Enlightenment" impersonality—the expressive and stylistic "zero sum" —of much academic journal publication. We also appreciate the rigor of review shown by Humanities' reviewers and readers, which has challenged contributors to strengthen their claims, thus making for a better, more useful collection.

Conflicts of Interest: The authors declare no conflict of interest.

\section{References}

Alcorn, Marshall W., Jr. 1994. Self-Structure as a Rhetorical Device: Modern Ethos and the Divisiveness of the Self. In Ethos: New Essays in Rhetorical and Critical Theory. Edited by James S. Baumlin and Tita French Baumlin. Dallas: Southern Methodist University Press, pp. 3-35.

Altes, Liesbeth Korthals. 2014. Ethos and Narrative Interpretation: The Negotiation of Values in Fiction. Lincoln: University of Nebraska Press.

Archer, Margaret S. 2001. Being Human: The Problem of Agency. Cambridge: Cambridge University Press.

Aristotle, On. 1926. Aristotle: The 'Art' of Rhetoric. Translated by John H. Freese. Loeb Classical Library. Cambridge: Harvard University Press.

Aristotle, On. 1932. The Rhetoric of Aristotle. Translated by Lane Cooper. New York: Appleton-Century-Crofts.

Aristotle, On. 1941. The Basic Works of Aristotle. Edited by Richard McKeon. Translated by W. Rhys Roberts. New York: Random.

Aristotle, On. 1991. Aristotle on Rhetoric: A Theory of Civic Discourse. Translated by George A. Kennedy. New York: Oxford University Press.

Bakhtin, Mikhail M. 1981. The Dialogic Imagination: Four Essays. Edited by Michael Holquist. Translated by Caryl Emerson, and Michael Holquist. Austin: University of Texas Press.

Bakhtin, Mikhail M. 1986. Speech Genres and Other Late Essays. Austin: University of Texas Press.

Barthes, Roland. 1986. The Death of the Author. In The Rustle of Language. Translated by R. Howard. New York: Hill and Wang, pp. 49-55.

Baumlin, James S. 1994. Introduction: Positioning Ethos in Historical and Contemporary Theory. In Ethos: New Essays in Rhetorical and Critical Theory. Edited by James S. Baumlin and Tita French Baumlin. Dallas: Southern Methodist University Press, pp. xi-xxxi.

Baumlin, James S. 2001. Ethos. In The Oxford Encyclopedia of Rhetoric. Edited by Thomas O. Sloane. New York: Oxford University Press, pp. 263-77.

Baumlin, James S., and Tita French Baumlin. 1994. On the Psychology of the Pisteis: Mapping the Terrains of Mind and Rhetoric. In Ethos: New Essays in Rhetorical and Critical Theory. Edited by James S. Baumlin and Tita French Baumlin. Dallas: Southern Methodist University Press, pp. 91-112.

Baumlin, James S., and Peter Scisco. 2018. Ethos and its Constitutive Role in Organizational Rhetoric. In Handbook of Organizational Rhetoric and Communication: Foundations of Dialogue, Discourse, Narrative, and Engagement. Edited by Robert Heath and Øyvind Ihlen. Hoboken: John Wiley and Sons, pp. 201-13.

Bourdieu, Pierre. 1991. Language and Symbolic Power. Edited by John B. Thompson. Translated by Gino Raymond, and Matthew Adamson. Cambridge: Harvard University Press.

Bové, Paul. 1985. Mendacious Innocents, or, The Modern Genealogist as Conscientious Intellectual: Nietzsche, Foucault, Said. In Why Nietzsche Now? Edited by Daniel O'Hara. Bloomington: Indiana University Press, pp. 359-88.

Burke, Kenneth. 1969. A Rhetoric of Motives. Berkeley: University of California Press.

Corder, Jim W. 1978. Varieties of Ethical Argument, With Some Account of the Significance of Ethos in the Teaching of Composition. Freshman English News 6: 1-23.

Corder, Jim W. 1985. Argument as Emergence, Rhetoric as Love. Rhetoric Review 4: 16-32. [CrossRef]

Corts, Thomas E. 1968. The Derivation of Ethos. Speech Monographs 35: 201-2. [CrossRef]

DeLashmutt, Michael W. 2011. Posthumanism. In Encyclopedia of Religion and Film. Santa Barbara: Greenwood, pp. 354-61.

Derrida, Jacques. 1981. Dissemination. Translated by Barbara Johnson. Chicago: University Chicago Press.

Epstein, Mikhail. 2012. The Transformative Humanities: A Manifesto. Translated by Igor Klyukanov. New York: Bloomsbury. 
Fleckenstein, Kristie S. 2016. A Reformer Rides: Radical Photographic Ethos in Frances E. Willard's A Wheel within a Wheel. In Rethinking Ethos: A Feminist Ecological Approach to Rhetoric. Edited by Kathleen J. Ryan, Nancy Myers and Rebecca Jones. Carbondale: Southern Illinois University Press, pp. 26-49.

Foucault, Michel. 1987. The Ethic of Care for the Self as a Practice of Freedom. In The Final Foucault. Edited by James Bernauer and David Rasmussen. Translated by J. D. Gauthier S. J. Boston: MIT, pp. 1-20.

Garver, Eugene. 1994. Aristotle's Rhetoric: An Art of Character. Chicago: University of Chicago Press.

Geertz, Clifford. 1973. The Interpretation of Cultures: Selected Essays by Clifford Geertz. New York: Basic Books.

Giddens, Anthony. 1991. Modernity and Self-Identity: Self and Society in the Late Modern Age. Cambridge: Polity.

Gilligan, Carol. 1982. In a Different Voice: Psychological Theory and Women's Development. Cambridge: Harvard University Press.

Goffman, Erving. 1959. The Presentation of Self in Everyday Life. Garden City: Doubleday.

Gorgias. 1990. Encomium of Helen. Edited by Patricia Bizzell and Bruce Herzberg. Boston: Bedford, pp. 40-42.

Grimaldi, William A. S. J. 1980. Aristotle, Rhetoric I: A Commentary. New York: Fordham University Press.

Grimaldi, William A. S. J. 1988. Rhetoric II: A Commentary. New York: Fordham University Press.

Gusdorf, Georges. 1965. Speaking. Translated by Paul T. Brockelman. Evanston: Northwestern University Press.

Hall, Stuart, and Paul Du Gay, eds. 1996. Who Needs Identity? In Questions of Cultural Identity. London: Sage, pp. 1-17.

Halloran, S. Michael. 1975. On the End of Rhetoric, Classical and Modern. College English 35: 621-31. [CrossRef]

Heidegger, Martin. 1978. Building Dwelling Thinking. In Heidegger: Basic Writings. Edited by David Farrell Krell. Translated by A. Hofstadter. New York: Harper, pp. 319-39. First published 1951.

Heidegger, Martin. 1949. Letter on Humanism. In Pathmarks. Edited by William McNeil. Translated by Frank A. Capuzzi. Cambridge: Cambridge University Press, pp. 239-76.

Hindman, Jane E. 2003. Thoughts on Reading 'The Personal': Toward a Discursive Ethics of Professional Critical Literacy. College English 66: 9-20. [CrossRef]

Hirsch, David H. 1991. The Deconstruction of Literature: Criticism after Auschwitz. Hanover: University Press of New England. Holland, Norman. 2011. The I and Being Human. New York: Routledge.

Homer. 1919. The Odyssey: Books 1-12. Translated by A. T. Murray. Loeb Classical Library. Cambridge: Harvard University Press.

Homer. 1924. The Iliad: Books 1-12. Translated by A. T. Murray. Loeb Classical Library. Cambridge: Harvard University Press.

Hyde, Michael J. 2004. Introduction: Rhetorically, We Dwell. In The Ethos of Rhetoric. Edited by Michael J. Hyde. Columbia: South Carolina Press, pp. xiii-xxviii.

Isocrates. 1990. Antidosis. In The Rhetorical Tradition: Readings from Classical Times to the Present. Edited by Patricia Bizzell and Bruce Herzberg. Boston: St. Martin's, pp. 50-54.

Jarratt, Susan C., and Nedra Reynolds. 1994. The Splitting Image: Contemporary Feminisms and the Ethics of Ethos. In Ethos: New Essays in Rhetorical and Critical Theory. Edited by James S. Baumlin and Tita French Baumlin. Dallas: Southern Methodist University Press, pp. 37-64.

Keller, David. 1997. Gleaning Lessons from Deep Ecology. Ethics and the Environment 2: 139-48.

Kennedy, George A. 1963. The Art of Persuasion in Greece. Princeton: Princeton University Press.

Kinneavy, James L., and Susan C. Warshauer. 1994. From Aristotle to Madison Avenue: Ethos and the Ethics of Argument. In Ethos: New Essays in Rhetorical and Critical Theory. Edited by James S. Baumlin and Tita French Baumlin. Dallas: Southern Methodist University Press, pp. 171-90.

Lacan, Jacques. 2004. Ecrits: A Selection. Translated by Bruce Fink. New York: Norton.

LeFevre, Karen Burke. 1987. Invention as a Social Act. Carbondale: Southern Illinois University Press.

Livingston, Paul M. 2015. Wittengenstein Reads Heidegger, Heidegger reads Wittgenstein: Thinking, Language Bounding World. In Beyond the Analytic-Continental Divide: Pluralistic Philosophy in the Twenty-First Century. Edited by Jeffrey A. Bell, Andrew Cutrofello and Paul M. Livingston. New York: Routledge, pp. 222-48.

Lovelock, James. 1979. Gaia: A New Look at Life on Earth. Oxford: Oxford University Press.

Lyotard, Jean-François. 1984. The Postmodern Condition: A Report on Knowledge. Translated by Geoff Bennington, and Brian Massumi. Minneapolis: University of Minnesota Press. First published 1979.

Mansfield, Nick. 2000. Subjectivity: Theories of the Self from Freud to Haraway. St. Leonards: Allen and Unwin.

Maton, Karl Habitus. 2014. Pierre Bourdieu: Key Concepts, 2nd ed.Edited by Michael Grenfell. London: Routledge, pp. 48-64. 
May, James M. 1988. Trials of Character: The Eloquence of Ciceronian Ethos. Chapel Hill: University of North Carolina Press. Merton, Robert K. 1973. The Sociology of Science: Theoretical and Empirical Investigations. Chicago: University of Chicago Press.

Miller, Carolyn R. 1994. Expertise and Agency: Transformation of Ethos in Human-Computer Interactions. In The Ethos of Rhetoric. Columbia: South Carolina Press, pp. 197-218.

Miller, Susan. 2007. Trust in Texts: A Different History of Rhetoric. Carbondale: Southern Illinois University Press.

Naess, Arne. 1973. The Shallow and the Deep, Long-Range Ecology Movement: A Summary. Inquiry 16: 95-100. [CrossRef]

Nietzsche, Friedrich. 1969. On the Genealogy of Morals. Translated by Walter Kaufmann. New York: Vintage. First Published 1887.

Noddings, Nel. 1984. Caring: A Feminine Approach to Ethics and Moral Education. Berkeley: University of California Press.

Oddo, John. 2014. The Chief Prosecutor and the Iraqi Regime: Intertextual Ethos and Transitive Chains of Authority. In Intertextuality and the 24-Hour News Cycle: A Day in the Rhetorical Life of Colin Powell's U.N. Address. East Lansing: Michigan State University Press, pp. 45-76.

Palmer-Mehta, Valerie. 2016. Andrea Dworkin's Radical Ethos. In Rethinking Ethos: A Feminist Ecological Approach to Rhetoric. Edited by Kathleen J. Ryan, Nancy Myers and Rebecca Jones. Carbondale: Southern Illinois University Press, pp. 50-70.

Perelman, Chaïm, and L. Olbrechts-Tyteca. 1969. The New Rhetoric: A Treatise on Argumentation. Translated by John Wilkinson, and Purcell Weaver. Notre Dame: University of Notre Dame Press.

Plato. 1966. Phaedrus. Translated by Harold North Fowler. Loeb Classical Library. Cambridge: Harvard University Press.

Reynolds, Nedra. 1993. Ethos as Location: New Sites for Understanding Discursive Authority. Rhetoric Review 11: 325-38. [CrossRef]

Sartre, Jean-Paul. 1993. Being and Nothingness. Translated by Hazel E. Barnes. New York: Washington Square. First published 1943.

Sennett, Richard. 1990. The Rhetoric of Racial Identity. In The Ends of Rhetoric: History, Theory, Practice. Edited by John Bender and David E. Wellbery. Stanford: Stanford University Presss, pp. 191-206.

Smith, Craig R. 2004. Ethos Dwells Pervasively: A Hermeneutic Reading of Aristotle on Credibility. In The Ethos of Rhetoric. Columbia: University of South Carolina Press, pp. 1-19.

Solmsen, Friedrich. 1941. The Aristotelian Tradition in Ancient Rhetoric. American Journal of Philology 62: 169-90.

Spellmeyer, Kurt. 1996. After Theory: From Textuality to Attunement with the World. College English 58: 893-913. [CrossRef]

Spivak, Gayatri Chakravorty. 1988. Can the Subaltern Speak? In Marxism and the Interpretation of Culture. Edited by Cary Nelson and Lawrence Grossberg. Urbana: University of Illinois Press, pp. 271-313.

Szasz, Thomas. 1978. The Myth of Psychotherapy: Mental Healing as Religion, Rhetoric, and Repression. Garden City: Anchor. Tedeschi, James T. 1986. Private and Public Experiences and the Self. In Public Self and Private Self. Edited by Roy F. Baumeister. New York: Springer, pp. 1-20.

Thomas, Douglas. 1993. Utilising Foucault's Nietzsche: Nietzsche, Genealogy, Autobiography. Journal of Nietzsche Studies 6: 103-29.

Thomas, Susan E., ed. 2007. What is the New Rhetoric? Newcastle: Cambridge Scholars.

Trigg, Roger. 1998. Rationality and Religion: Does Faith Need Reason? London: Blackwell.

Voloshinov, Valentin Nikolaevich. 1986. Marxism and the Philosophy of Language. Translated by Ladislav Matejka, and I. R. Titunik. Cambridge: Harvard University Press.

Waite, Stacey. 2016. The Unavailable Means of Persuasion: A Queer Ethos for Feminist Writers and Teachers. Edited by Kathleen J. Ryan, Nancy Myers and Rebecca Jones. Carbondale: Southern Illinois University Press, pp. 71-88. White, Stephen K. 2009. The Ethos of a Late-Modern Citizen. Cambridge: Harvard University Press.

Wisse, Jakob. 1989. Ethos and Pathos from Aristotle to Cicero. Amsterdam: Adolf M. Hakkert.

Wittgenstein, Ludwig. 1953. Philosophical Investigations. Translated by G. E. M. Anscombe. New York: MacMillan.

(C) 2018 by the authors. Licensee MDPI, Basel, Switzerland. This article is an open access article distributed under the terms and conditions of the Creative Commons Attribution (CC BY) license (http:/ / creativecommons.org/licenses/by/4.0/). 